\title{
Cyclopentenone Prostaglandins: Biologically Active Lipid Mediators Targeting Inflammation
}

Bohae Rachel Leet, May Hnin Paing ${ }^{\dagger}$ and Neelam Sharma-Walia*t

H. M. Bligh Cancer Research Laboratories, Department of Microbiology and Immunology, Chicago Medical School, Rosalind Franklin University of Medicine and Science, North Chicago, IL, United States

Cyclopentenone prostaglandins (CyPGs) are biologically active lipid mediators, including $P G A_{2}, P G A_{1}, P G J_{2}$, and its metabolites. cyPGs are essential regulators of inflammation, cell proliferation, apoptosis, angiogenesis, cell migration, and stem cell activity. cyPGs biologically act on multiple cellular targets, including transcription factors and signal transduction pathways. cyPGs regulate the inflammatory response by interfering with NF-kB, AP-1, MAPK, and JAK/STAT signaling pathways via both a group of nuclear receptor peroxisome proliferator-activated receptor-gamma (PPAR$\gamma$ ) dependent and PPAR- $\gamma$ independent mechanisms. cyPGs promote the resolution of chronic inflammation associated with cancers and pathogen (bacterial, viral, and parasitic) infection. cyPGs exhibit potent effects on viral infections by repressing viral protein synthesis, altering viral protein glycosylation, inhibiting virus transmission, and reducing virus-induced inflammation. We summarize their anti-proliferative, pro-apoptotic, cytoprotective, antioxidant, anti-angiogenic, anti-inflammatory, proresolution, and anti-metastatic potential. These properties render them unique therapeutic value, especially in resolving inflammation and could be used in adjunct with other existing therapies. We also discuss other $\alpha, \beta$-unsaturated carbonyl lipids and cyPGs like isoprostanes (IsoPs) compounds.

\section{Keywords: prostaglandins, PPAR- $\gamma$, viral (or virus), inflammation, antiviral}

Abbreviations: AD, Alzheimer's disease; AP-1, activating protein-1; ALS, amyotrophic lateral sclerosis; AGMK, African green monkey kidney; COX, cyclooxygenase; CCR, chemokine receptors; CTL, cytotoxic T lymphocytes; CREB, cyclic AMP-responsive element-binding; cyPGs, cyclopentenone PGs; COPD, chronic obstructive pulmonary disease; DCs, dendritic cells; DGLA, dihomo g-linolenic acid; EAE, experimental allergic encephalomyelitis; EBV, Epstein-Barr virus; ERK, extracellular signal-regulated kinases; EMT, epithelial to mesenchymal transition; FRK, c-Fos-regulating kinases; GMCSF, granulocyte-macrophage colony-stimulating factor; GR, glutathione reductase; GPx, glutathione peroxidase 1; GCS, c-glutamylcysteine synthetase; HCMV, human cytomegalovirus; HDACs, histone deacetylases; HO-1, heme oxygenase1; HSV, herpes simplex virus; Hep-2, human epithelial type 2; HSP70, heat shock protein70; HTLV-1, human T-cell leukemia virus type-I; hTERT, human telomerase reverse transcriptase; ICAM-1, intercellular adhesion molecule 1; IBD, inflammatory bowel disease; IsoPs, isoprostanes; IKK, IкB kinase; JAK, Janus kinase; Keap1, Kelch-like ECHassociated protein 1; KSHV, Kaposi's sarcoma herpesvirus; LBD, ligand-binding domain; mTOR, mammalian target of rapamycin; MMP-9, matrix metalloproteinase; Nrf2, NF-E2-related nuclear factor erythroid-2; NSCLC, non-small cell lung carcinoma; NE, nanoemulsion; NGS, next-generation sequencing; NLS, nuclear localization sequence; NSAIDs, non-steroidal anti-inflammatory drugs; NQO1, NAD(P)H dehydrogenase quinone 1; PAI-1, plasminogen activator inhibitor-1; PD-1, programmed cell death protein-1; PDL-1, programmed cell death ligand-1; PG, prostaglandin; PUFA, polyunsaturated fatty acid; $15-\mathrm{PGDH}, 15$-hydroxyprostaglandin dehydrogenase; $\mathrm{PLA}_{2}$, phospholipase $\mathrm{A}_{2}$; PPAR- $\gamma$, peroxisome proliferator activated receptor-gamma; ROS, reactive oxygen species; RTT, Rett syndrome; SOCS, suppressor of cytokine signaling; SLN, solid lipid nanoparticles; SOD, superoxide dismutase; SLOS, Smith-Lemli-Opitz syndrome; TAR, transactivation response element; TGF- $\beta$, transforming growth factor- $\beta$; TGZ, troglitazone; $\mathrm{TXA}_{2}$, thromboxane $\mathrm{A}_{2}$; uPA, urokinase plasminogen activator; VEGF, vascular endothelial growth factor; VSV, vesicular stomatitis virus; VZV, varicella zoster virus. 


\section{INTRODUCTION}

Prostaglandins (PGs) are a group of lipids or oxygenated derivatives of arachidonic acid (AA) that sustain homeostatic functions and mediate the inflammatory response (Aoki and Narumiya, 2012). There are two types of PGs: conventional or classic PGs and cyclopentenone PGs (cyPGs). Examples of traditional $\mathrm{PGs}$ are $\mathrm{PGD}_{2}, \mathrm{PGE}_{2}$, prostacyclin $\left(\mathrm{PGI}_{2}\right)$, $\mathrm{PGF}_{2 \alpha}$, and thromboxane $\mathrm{A}_{2}\left(\mathrm{TXA}_{2}\right)$, while the members of cyPGs include $\mathrm{PGA}_{1}, \mathrm{PGA}_{2}, \mathrm{PG}_{2}$, and metabolites of $\mathrm{PGJ}_{2}$, such as 15-Deoxy- $\Delta-{ }^{12,14}$-Prostaglandin $\mathrm{J}_{2}$ (15d$\mathrm{PGJ}_{2}$ ) and $\Delta^{12}-\mathrm{PGJ}_{2}$. As the name implies, cyPGs contain a cyclopentenone ring structure with a highly reactive $\alpha, \beta$ unsaturated carbonyl group, which can alter many proteins and their functional properties covalent attachments with thiol groups of the proteins (Straus and Glass, 2001). cyPGs are potent bioactive molecules and have a wide range of functions (Burstein, 2020). cyPGs can repress inflammatory responses, inhibit cell growth, angiogenesis, and increase apoptosis. cyPGs can interfere with virus infections and cancer development, indicating their potential to serve as therapeutic agents. This review discusses cyPGs biosynthesis, mechanism of action, functions, and their effects on virus infection and cancer development. Despite the existing knowledge, the resolving, antiviral, anti-inflammatory, and anticancer potential of cyPGs have been minimally explored and warrant further attention.

\section{BIOSYNTHESIS OF CYCLOPENTENONE PROSTAGLANDINS (PGA 1 , PGA 2 , AND $\mathrm{PGJ}_{2}$ AND ITS METABOLITES)}

AA is liberated from membrane phospholipids by the enzyme phospholipase $\mathrm{A}_{2}\left(\mathrm{PLA}_{2}\right)$ (Vane and Botting, 1990). Myosin, an actin-binding protein, is phosphorylated when there is an increase in intracellular calcium levels, causing $\mathrm{PLA}_{2}$ to translocate from the cytoplasm to the intracellular membrane to access the phospholipids. Arachidonate is metabolized to $\mathrm{PGG}_{2}$ by cyclooxygenase (COX) 1 and 2 (COX-1 and COX-2), which are contained in the endoplasmic reticulum (ER) and nuclear membranes (Vane and Botting, 1990; Hanna and Hafez, 2018) (Figure 1). PGG $_{2}$ is converted into $\mathrm{PGH}_{2}$ by hydroxyperoxidase. Unstable $\mathrm{PGH}_{2}$ diffuses from the ER lumen to the cytoplasm through the ER membrane. Due to its unstable nature, $\mathrm{PGH}_{2}$ is enzymatically converted into different PGs, including $\mathrm{PGI}_{2}, \mathrm{PGF}_{2}$, and $\mathrm{TXA}_{2}$, through the action of specific PG synthases (Figure 1). When $\mathrm{PGH}_{2}$ is acted upon by $\mathrm{PGD}_{2}$ synthase, $\mathrm{PGD}_{2}$ is created. $\mathrm{PGD}_{2}$ is unstable and spontaneously undergoes non-enzymatic dehydration to yield either $15 \mathrm{~d}-\mathrm{PGD}_{2}$ or $\mathrm{PGJ}_{2}$ (Figure 1). Further dehydration and a 13, 14 double bond rearrangement of $\mathrm{PGJ}_{2}$ yield 15 -Deoxy- $\Delta-{ }^{12,14}$-prostaglandin $\mathrm{J}_{2}\left(15 \mathrm{~d}-\mathrm{PGJ} \mathrm{J}_{2}\right)$ in an albumin-independent manner, while $\mathrm{PGJ}_{2}$ dependent on serum albumin results in $\Delta 12-\mathrm{PGJ}_{2}$ (Figueiredo-Pereira et al., 2014). PGs of the $\mathrm{J}$ series are synthesized in vivo as $\Delta 12-\mathrm{PGJ}_{2}$ is a natural component of human body fluids.
Its synthesis is inhibited by treatment with COX inhibitors (Hirata et al., 1988). When $\mathrm{PGH}_{2}$ is acted upon by $\mathrm{PGE}_{2}$ synthase, $\mathrm{PGE}_{2}$ is formed. Dehydration of $\mathrm{PGE}_{2}$ leads to PGA $_{2}$ (Hamberg and Samuelsson, 1966; Nugteren et al., 1966) (Figure 1). 15d-PGJ 2 could function in both an autocrine and paracrine manner and can be produced intracellularly and extracellularly via non-enzymatic conversion of $\mathrm{PGD}_{2}$ (Shibata et al., 2002).

The formation of the cyclopentenone $\mathrm{PGA}_{1}$ has a different genesis pathway compared to the other members of its family $\left(\mathrm{PGA}_{2}\right.$ and $\left.\mathrm{PGJ}_{2}\right)$. The formation of $\mathrm{PGA}_{1}$ begins with linoleic acid (LA). In the human diet, linoleic acid is the most consumed polyunsaturated fatty acid (PUFA) (Whelan and Fritsche, 2013). Linoleic acid, an essential omega $6(n=6)$ fatty acid, is converted to $\gamma$-linoleic acid (GLA; GLA, 18:3-6) through the membranebound enzyme 6-desaturase ( $\Delta-6$-desaturase). GLA is then metabolized to dihomo $\gamma$-linolenic acid (DGLA, 20:3-6) by a $\Delta 6$ elongase. From this point, DGLA can be converted into AA by the enzyme 5-Desaturase, or $\mathrm{PGE}_{1}$ by the enzyme COX. $\mathrm{PGE}_{1}$ undergoes dehydration to become PGA 1 (Kapoor and Huang, 2006; Kapoor et al., 2007).

$15 \mathrm{~d}-\mathrm{PGJ}_{2}$ acts via G-protein-coupled seven-transmembrane $\mathrm{PGD}_{2}$ receptors ( $\mathrm{D}$ prostanoid; $\mathrm{DP}_{1}$ and $\mathrm{DP}_{2}$ ) and through interaction with intracellular targets (Kato et al., 1986; Kim et al., 1993; Negishi and Katoh, 2002). DP 2 (chemoattractant receptor-homologous molecule or GPR44 or CD294) is expressed on Th2 cells, eosinophils, activated mast cells, and basophils (Negishi and Katoh, 2002; Nagata et al., 2017). PGE $1 / \mathrm{PGA}_{1}$ is native/endogenous ligands of orphan nuclear receptor-related 1 protein (Nurr1; NR4A2) and activates its transcriptional function (Negishi and Katoh, 2002; Pearen and Muscat, 2010; Kurakula et al., 2014).

\section{CYCLOPENTENONE PROSTAGLANDINS AND INFLAMMATION}

\section{Cyclopentenone Prostaglandins in Various Diseases}

$15 \mathrm{~d}-\mathrm{PGJ} \mathrm{J}_{2}$ is an immune regulator to modulate human autoimmune diseases as multiple sclerosis (MS), experimental allergic encephalomyelitis (EAE), polymyositis, Bechet's diseases, rheumatoid arthritis (RA), atopic dermatitis, systemic lupus erythematosus (SLE) (Li and Pauza, 2009), and age-related neurodegenerative diseases, including Alzheimer's (AD) and Parkinson's disease (PD) (Koharudin et al., 2011). $\gamma \Delta \mathrm{T}$ cells have been studied in context with autoimmune diseases in humans. $\gamma \Delta \mathrm{T}$ cells possess the cytotoxic activity and produce IFN- $\gamma$, tumor necrosis factor-alpha; $\operatorname{TNF}-\alpha$, and chemokines involved in recruiting monocytes and macrophages. The induction of cytokines and secretion of interleukin-17 (IL17) contributes to inflammatory processes and promotes autoimmunity. $15 \mathrm{~d}-\mathrm{PGJ}_{2}$, along with rosiglitazone (Avandia), suppressed $\gamma \Delta \mathrm{T}$ cell proliferation in response and downregulated cytokine production ( $\mathrm{Li}$ and Pauza, 2009). 15d-PGJ 2 also plays an essential regulatory role in osteosarcoma, bone 


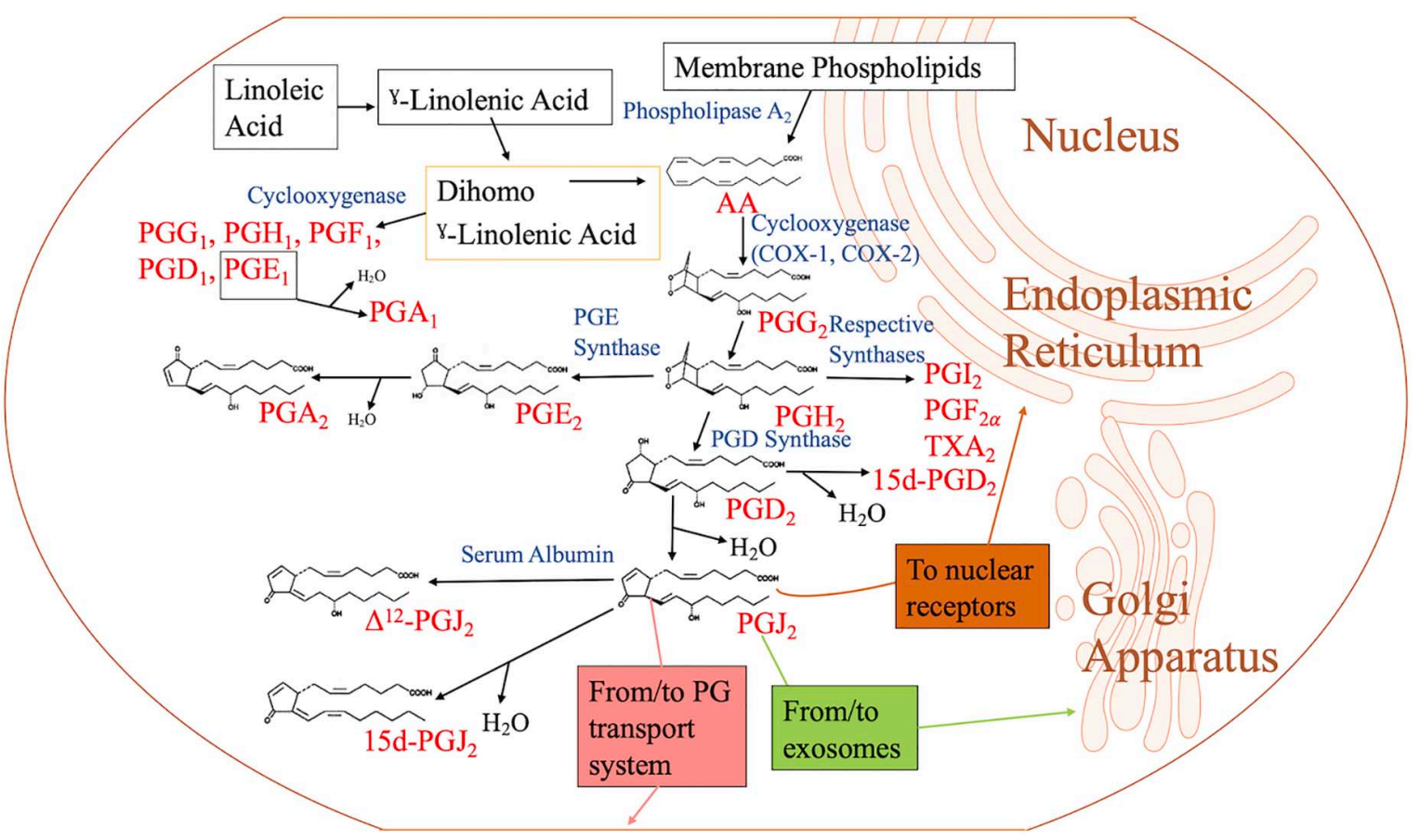

FIGURE 1 | Biosynthesis of cyclopentenone prostaglandins. When the cell is activated by stressful stimuli, such as mechanical trauma, interferon, interleukin, or growth factors, the enzyme phospholipase $\mathrm{A}_{2}$ moves from the cytoplasm to intracellular membranes to liberate arachidonic acid (AA) from the nuclear envelope or endoplasmic reticulum. AA is converted by cyclooxygenase-1 (COX-1) or cyclooxygenase-2 (COX-2) to prostaglandin $\mathrm{G}_{2}\left(\mathrm{PGG}_{2}\right)$, followed by hydroperoxidation of $P G G_{2}$ to $P \mathrm{PH}_{2}$. $P \mathrm{PH}_{2}$ is converted to other $\mathrm{PGH}_{2}$ metabolites such as $P \mathrm{GD}_{2}, \mathrm{PGE}_{2}, \mathrm{PGF}_{2}, \mathrm{PG}_{2}$, and thromboxane $\mathrm{A}_{2}\left(\mathrm{TX} \mathrm{A}_{2}\right.$ ) by their respective synthases. Of the metabolites, $P G D_{2}$ is dehydrated to form $J_{2} P G s$. $P G J_{2}$ may be located in exosomes, transport systems, or nuclear receptors to execute its function. $P G E_{2}$ is dehydrated to form $\mathrm{PGA}_{2}$. $\mathrm{PGA}_{1}$ is a metabolite of linoleic acid, which is obtained through diet.

metastases, and bone metabolism (Kitz et al., 2011; Kim et al., 2015).

\section{Cyclopentenone Prostaglandins Elicit Anti-inflammatory Responses via Regulating Transcription Factors Crucial for Inflammatory Response}

$15 \mathrm{~d}-\mathrm{PGJ}_{2}$ directly inhibits multiple steps in the NF- $\mathrm{B}$ signaling pathway and NF-кB-dependent gene expression (Straus et al., 2000). NF- $\kappa$ B represents a family of structurally related inducible

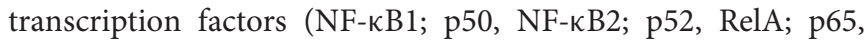
RelB, and c-Rel) located in the cytoplasm, which activates genes responsible for inflammation and innate and adaptive immunity (Senftleben et al., 2001). The NF- $\kappa$ B proteins are typically sequestered in the cytoplasm by a family of inhibitory proteins, including I $\mathrm{B}$ family members, which sterically block the nuclear localization sequence (NLS) of NF-кB (Senftleben et al., 2001; Sun, 2017). The IкB kinase (IKK) complex is crucial for the activation of NF- $\kappa \mathrm{B}$, as it can degrade the NF- $\kappa \mathrm{B}$ inhibitor I $\mathrm{B}$ through phosphorylation, subsequently freeing NF$\kappa B$ (Senftleben et al., 2001). NF- $\kappa B$ is involved in the pathogenesis of inflammatory diseases, including RA, inflammatory bowel disease (IBD), MS, atherosclerosis, SLE, type 1 diabetes, chronic obstructive pulmonary disease (COPD), and asthma (Pai and Thomas, 2008). NF- $\mathrm{KB}$ activation induces proinflammatory cytokines (IL-1 $\beta$, IL-1, IL-2, IL-6, IL-8, and TNF- $\alpha$ ) (Lawrence, 2009; Wang et al., 2014) and regulates inflammasome function (Guo et al., 2015) in both innate and adaptive immune cells. $\mathrm{PGA}_{1}$, another cyPG, is also a potent inhibitor of $\mathrm{NF}-\kappa \mathrm{B}$ activation in human cells by inhibiting phosphorylation and preventing degradation of the NF- $\kappa$ B inhibitor IкB- $\alpha$ (Rossi et al., 1997). The $\alpha, \beta$-unsaturated carbonyl group in the cyPGs, when reactive, can undergo a Michael reaction with the cysteine nucleophile at position 179 on the IKK $\beta$ subunit of the IKK complex. This cysteine is located in the activation loop of the enzyme, and the alkylation of the cysteine inhibits the phosphorylation of the activation loop. Therefore, cyPGs inhibit IKK complex activity by directly modifying the IKK $\beta$ subunit (Rossi et al., 2000). By doing so, the degradation ІкB is inhibited, and NF- $\mathrm{B}$ is unable to enter the nucleus.

$15 \mathrm{~d}-\mathrm{PGJ}_{2}$ inhibits transcription factor activity of activating protein-1 (AP-1) (Perez-Sala et al., 2003). AP-1 is composed of dimeric complexes, which included members of four families of DNA-binding proteins such as Jun, Fos, ATF/cyclic AMPresponsive element-binding (CREB), and musculoaponeurotic fibrosarcoma (Maf) (Milde-Langosch, 2005; Hernandez et al., 2008). 15d-PGJ 2 covalently modifies c-Jun and directly inhibits the DNA binding activity of AP-1 (Perez-Sala et al., 2003). AP-1 plays critical roles in inflammation, proliferation, innate immune response and stimulates growth factors and proinflammatory cytokines mediated by serine/threonine kinases as c-Jun 
NH2-terminal kinases (JNK), p38, extracellular signal-regulated kinases (ERK), and c-Fos-regulating kinases (FRK) MAP kinase pathways (Lin et al., 1995; Minden et al., 1995).

$15 \mathrm{~d}-\mathrm{PGJ} \mathrm{J}_{2}$ non-specifically inhibits Signal transducer and activator of transcription (STAT) (Ji et al., 2005) and Janus kinase (JAK)-STAT signaling pathway in lymphocytes (Kim et al., 2005). STAT1 can be activated upon tyrosine phosphorylation by JAK1 tyrosine kinase (Mowen and David, 2000). Upon activation, STAT/STAT interactions occur immediately, and dimerized STATs can then enter the nucleus and regulate the transcription of inflammatory genes of cytokine and interferon signaling (Seif et al., 2017).

\section{Anti-inflammatory, Anti-tumorigenic, Anti-angiogenic, Anti-metastatic, Anti-fibrotic, Resolving, and Antioxidant Modes of Action of Cyclopentenone Prostaglandins}

cyPGs, such as $15 \mathrm{~d}-\mathrm{PGJ}_{2}, \mathrm{PGJ}_{2}, \mathrm{PGA}_{1}$, and $\mathrm{PGA}_{2}$, can activate peroxisome proliferator-activated receptor-gamma (PPAR- $\gamma$ ), and many of their biological functions are either PPAR- $\gamma$ dependent or independent (Mukherjee et al., 1994; Ricote et al., 1998b; Yagami et al., 2018). PPAR- $\gamma$ is one of the members (PPAR- $\alpha$, PPAR- $\delta$, and PPAR- $\gamma$ ) of the nuclear receptor superfamily and is a ligand-dependent transcription factor. The ligand $15 \mathrm{~d}-\mathrm{PGJ}_{2}$ activates PPAR- $\gamma$, and PPAR- $\gamma$ then forms a heterodimer with retinoid $\mathrm{X}$ receptor (RXR) in the cytoplasm. Complex enters the nucleus (Scher and Pillinger, 2005; Li et al., 2019). This complex binds to specific PPAR response element (PPRE) regions in the DNA to activate different target genes (Forman et al., 1996).

\section{Anti-inflammatory Actions}

Peroxisome proliferator-activated receptor-gamma inhibits TNF$\alpha$, IL-6, inducible NO synthase (iNOS), gelatinase B, and COX-2 by acting as an antagonist to AP-1 and NF- $\kappa$ B (Welch et al., 2003). This inhibition mode was observed in activated macrophages expressing high levels of PPAR- $\gamma$ (Ricote et al., 1998a,b; Straus et al., 2000). In general, when IFN- $\gamma$ stimulated peritoneal macrophages were treated with $15 \mathrm{~d}-\mathrm{PGJ}_{2}$, instead of observing activated macrophages, morphological features classic of resting cells were seen (Ricote et al., 1998a,b). 15d-PGJ 2 treatment inhibited the induction of iNOS transcription by inhibiting the binding of AP-1 and NF- $\mathrm{B}$ on iNOS promoter (Ricote et al., $1998 \mathrm{a}, \mathrm{b})$. Usually, iNOS is upregulated in activated macrophages accompanied by the overproduction of nitric oxide (NO), which causes inflammation (Sharma and Staels, 2007). Excess NO also induces s-nitrosylation of Sirt1, an inhibitor of p65 NF$\kappa \mathrm{B}$, which inactivates Sirt1 and enhances pro-inflammatory response (Nakazawa et al., 2017). 15d-PGJ 2 treatment inhibits matrix metalloproteinase (MMP-9) or also called Gelatinase B in activated macrophages (Ricote et al., 1998a,b) at the transcription level. Inhibition by $15 \mathrm{~d}-\mathrm{PGJ}_{2}$ is mediated at the level of AP1 binding as MMP-9 transcriptional activation is dependent on AP-1 (Saarialho-Kere et al., 1993). 15d-PGJ 2 and TZDs reduced dendritic cells (DCs) stimulation with toll-like receptor
(TLR) ligands via the MAP kinase and NF- $\kappa$ B pathways (Appel et al., 2005). In RAW264.7 cells, monocyte/macrophage-like cell lineage stimulated with LPS, a similar outcome to that of Jurkat cells was observed when treated with cyPGs (Straus et al., 2000). A different result was observed in HeLa cells, strengthening the fact that cyPGs' effect is cell type specific. Instead of inhibiting IKK complex activity, cyPGs impede the binding of NF- $\kappa \mathrm{B}$ to DNA since p50 and p65 have cysteine residues at C62 and C38, respectively. Alkylation of these cysteines via the Michael reaction results in the inhibition of the binding of NF- $\kappa$ B to DNA (Straus et al., 2000).

In human astrocytes treated with $15 \mathrm{~d}-\mathrm{PGJ} \mathrm{J}_{2}, \mathrm{NF}-\kappa \mathrm{B}$ was inhibited from binding to the COX-2 promoter on DNA (Janabi, 2002). In glial cells, $15 \mathrm{~d}-\mathrm{PGJ}_{2}$ induces the transcription of suppressor of cytokine signaling 1 and 3 (SOCS1 and SOCS3) can inhibit JAK, eventually inhibiting the transcription of inflammatory genes (Park E. J. et al., 2003; Park S. H. et al., 2003). 15d-PGJ 2 inhibited the JAK/STAT1 mediated interferon regulatory factor-1 (IRF-1) expression, thereby decreasing the IFN- $\gamma$-induced costimulatory molecule B7-H1 expression needed by tumors to evade the host immune response (Seo et al., 2014). 15d-PGJ 2 inhibits lethal anthrax toxin (LT) activation of the NLRP1 and nigericin-mediated activation of the NLRP3 inflammasome and associated IL-1 $\beta$ release (Maier et al., 2015). $15 \mathrm{~d}-\mathrm{PG} \mathrm{J}_{2}$ mitigates the macrophage hyperinflammatory response (Monroy et al., 2007).

$\mathrm{PGD}_{2}$ and the $\mathrm{J}_{2}$-series $\mathrm{PGJ}_{2}$ and $\Delta 12-\mathrm{PGJ}_{2}$ are critical components of the inflammatory response within adipose tissue during obesity thus producing inflammation-related adipokines implicated in insulin sensitivity (Peeraully et al., 2006). 15d$\mathrm{PGJ}_{2}$ is the most potent inducer of fat cell (adipocyte) differentiation in vitro (Forman et al., 1995; Bell-Parikh et al., 2003). $\mathrm{PGD}_{2}, \mathrm{PGJ}_{2}$, and $\Delta 12-\mathrm{PGJ}_{2}$ treatment strongly downregulates the production of leptin, a hormone secreted by adipocytes (Peeraully et al., 2006).

\section{Anti-tumorigenic Actions}

$15 \mathrm{~d}-\mathrm{PGJ} \mathrm{J}_{2}$ exerts antitumor activity by regulating the $\mathrm{Myc} / \mathrm{Mad} / \mathrm{max}$ transcription factors to promote cell apoptosis, tubulin binding activity, inhibiting the expression of human telomerase reverse transcriptase (hTERT), enhancing TRAILinduced apoptosis by downregulating AKT phosphorylation, reactive oxygen species (ROS)-dependent cell death pathway, ROS-dependent AKT activation, inhibition of COX-2, STAT3, cell cycle (G2/M or G1) blockade, inhibition of vascular endothelial factor (VEGF), growth and expansion of tumor stem cells in gastric cancer (Inoue et al., 2000; Sato et al., 2000; Takashima et al., 2001; Yuan et al., 2005; Chearwae and Bright, 2008; Dionne et al., 2010; Li et al., 2017), oral squamous cell carcinoma (Nikitakis et al., 2002), leukemia (Han et al., 2007), lymphoma (Inoue et al., 2000; Sato et al., 2000; Takashima et al., 2001; Yuan et al., 2005; Chearwae and Bright, 2008; Dionne et al., 2010; Li et al., 2017), oesophageal cancer (Takashima et al., 2001), endometrial cancer (Li and Narahara, 2013), breast cancer (Cocca et al., 2009), osteosarcoma (Yen et al., 2014), and brain tumors (Inoue et al., 2000; Sato et al., 2000; $\quad$ Takashima et al., 2001; $\quad$ Yuan et al., 2005; 
TABLE 1 | Biological effects of cyclopentenone prostaglandins.

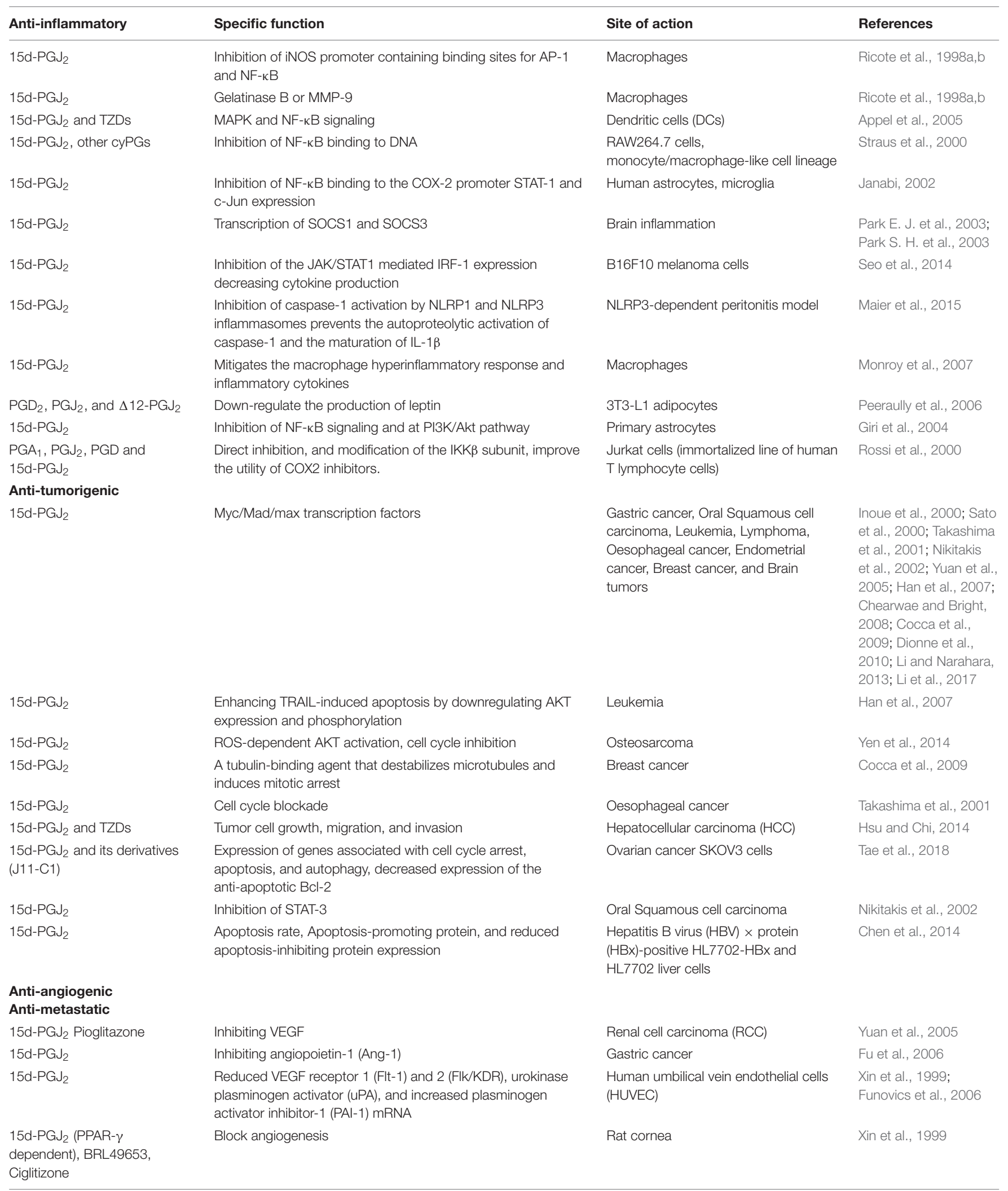


TABLE 1 | Continued

\begin{tabular}{|c|c|c|c|}
\hline Anti-inflammatory & Specific function & Site of action & References \\
\hline $\begin{array}{l}15 \mathrm{~d}-\mathrm{PG} \mathrm{J}_{2} \mathrm{HO}-1 \text {-dependent } \\
\text { mechanism }\end{array}$ & NF-кB and AP-1 mediated MMP-9 expression and invasion & MCF-7 breast cancer cells & Jang et al., 2020 \\
\hline $15 d-P G J_{2}$ & Disassembled focal adhesions, downregulation of FAK signaling & Renal cell carcinoma (RCC) metastasis & Yamamoto et al., 2020 \\
\hline \multicolumn{4}{|l|}{ Antioxidant } \\
\hline $15 d-P G J_{2}$ & Nrf2-Keap1 signaling pathway & Atherosclerosis & $\begin{array}{l}\text { Itoh et al., 2004; } \\
\text { Levonen et al., 2004; } \\
\text { Mochizuki et al., } 2005\end{array}$ \\
\hline $15 d-P G J_{2}$ & $\begin{array}{l}\mathrm{HO}-1, \mathrm{SOD} \text {, catalase, } \mathrm{NAD}(\mathrm{P}) \mathrm{H} \text { dehydrogenase quinone } 1 \\
\text { (NQO1), c-glutamylcysteine synthetase (GCS), glutathione } \\
\text { reductase }(\mathrm{GR}) \text {, glutathione peroxidase } 1 \text { (GPx) }\end{array}$ & Pleurisy, atherosclerosis & $\begin{array}{l}\text { Diers et al., 2010; Itoh } \\
\text { et al., 2004; Kansanen } \\
\text { et al., 2009; Magesh } \\
\text { et al., } 2012\end{array}$ \\
\hline $15 d-P G J_{2}$ & $\begin{array}{l}\text { 15-PGDH gene expression, protein level, and its activity, AP-1 } \\
\text { and } \mathrm{HO}-1\end{array}$ & Human colon cancer cell line HCT-116 & $\begin{array}{l}\text { Park and Na, 2019a,b; } \\
\text { Tauber and Parker, } \\
2019\end{array}$ \\
\hline $15 d-P G J_{2}$ & $\begin{array}{l}\text { elF2 } \alpha \text { phosphorylation, Activation of Integrated stress response } \\
\text { (ISR) }\end{array}$ & Neurodegenerative diseases & $\begin{array}{l}\text { Park and Na, 2019a,b; } \\
\text { Tauber and Parker, } \\
2019\end{array}$ \\
\hline \multicolumn{4}{|l|}{ Resolving inflammation } \\
\hline $15 d-P G J_{2}$ & $\begin{array}{l}\text { Cytoprotective, Shifting } P G \text { production from } P E_{2} \text { to } P G D_{2} \text { and } \\
15 d-P G J_{2}\end{array}$ & $\begin{array}{l}\text { Dextran sodium sulfate-induced colitis } \\
\text { in the rat and TNF- } \alpha \text {-induced activation } \\
\text { of PG production and PG synthase } \\
\text { expression in cultured human } \\
\text { peripheral blood monocytes (hPBMC) }\end{array}$ & Niro et al., 2010 \\
\hline $15 d-P G J_{2}$ & $\begin{array}{l}\text { DP1 receptor activation checkpoint controller of } \\
\text { cytokine/chemokine synthesis as well as leukocyte influx and } \\
\text { efflux }\end{array}$ & Self-resolving peritonitis & Rajakariar et al., 2007 \\
\hline $15 d-P G J_{2}$ & PPAR- $\gamma$ and CD36 expression & Enhance hematoma resolution & Flores et al., 2016 \\
\hline $15 d-P G J_{2}$ & $\begin{array}{l}\text { Inhibition of pro-inflammatory cytokines, such as IL-5, IL-13, } \\
\text { IL-17, TNF- } \alpha \text { Inhibition of NF-кB phosphorylation }\end{array}$ & $\begin{array}{l}\text { Peribronchial accumulation of } \\
\text { eosinophils and neutrophils, } \\
\text { subepithelial fibrosis, and also mucus } \\
\text { exacerbation }\end{array}$ & Coutinho et al., 2017 \\
\hline \multicolumn{4}{|l|}{$\begin{array}{l}\text { Prostanylation and protein } \\
\text { modification }\end{array}$} \\
\hline $\mathrm{PGE}_{1}$ and $\mathrm{PGA}_{1}$ & $\begin{array}{l}\text { Interact with the ligand-binding domain (LBD) of orphan nuclear } \\
\text { receptor Nurr1, neuroprotective, enhanced expression of Nurr1 } \\
\text { target genes in midbrain dopaminergic (mDA) neurons and } \\
\text { improved motor deficits }\end{array}$ & Mouse models of Parkinson's disease & Rajan et al., 2020 \\
\hline $15 d-P G J_{2}$ and $P G A_{1}$ & $\begin{array}{l}\mathrm{IKK} \alpha \text { and } \beta, \mathrm{NF}-\kappa \mathrm{B} \text { P65 and P50 subunits cysteine modification } \\
\text { at various positions }\end{array}$ & Inhibition of NF-кB pathway & $\begin{array}{l}\text { Castrillo et al., 2000; } \\
\text { Rossi et al., 2000; } \\
\text { Cernuda-Morollon } \\
\text { et al., } 2001\end{array}$ \\
\hline $15 d-P G J_{2}$ and $P G A_{1}$ & $\mathrm{H}$-Ras modification at various cysteines & Activation of H-Ras & Oliva et al., 2003 \\
\hline $15 d-P G J_{2}$ & c-Jun and c-Fos modification at various cysteines & Inhibition & Perez-Sala et al., 2003 \\
\hline$P A_{1}$ & Thioredoxin, thioredoxin reductase, and Keap1 & Inhibition & $\begin{array}{l}\text { Levonen et al., 2001, } \\
\text { 2004; Shibata et al., } \\
\text { 2003a; Itoh et al., } 2004\end{array}$ \\
\hline $15 d-P G J_{2}$ & Proteasome & Inhibition & Shibata et al., 2003b \\
\hline
\end{tabular}

Chearwae and Bright, 2008; Dionne et al., 2010; Li et al., 2017) (Table 1). Transforming growth factor- $\beta$ (TGF- $\beta$ ) induces cell growth, cell migration, and epithelial to mesenchymal transition (EMT) and promotes HCC progression (Giannelli et al., 2014). Interestingly, TZDs and $15 \mathrm{~d}-\mathrm{PGJ}_{2}$ display antitumor effects on HCC (Hsu and Chi, 2014). PPAR- $\gamma$ activation inhibits TGF- $\beta$ expression via dephosphorylation of zinc finger transcription factor-9 (Zf9) (Lee et al., 2006). Zf9 is crucial for TGFß1 gene regulation, and a phosphorylated form of $\mathrm{Zf} 9$ transactivates the TGFß1 promoter (Kim et al., 1998).
$15 \mathrm{~d}-\mathrm{PGJ} \mathrm{J}_{2}$ and its derivatives exert antitumor activity by selectively modulating the expression of genes associated with cell cycle arrest, apoptosis, and autophagy (Inoue et al., 2000; Sato et al., 2000; Takashima et al., 2001; Yuan et al., 2005; Chearwae and Bright, 2008; Dionne et al., 2010; Li et al., 2017). Notably, J11-C1 is a novel candidate of class III histone deacetylases (HDACs) called Sirtuin SIRT1 inhibitor with anticancer activity. SIRTs are involved in biological functions, including aging, energy mobilization, and stress responses. SIRTs regulate cancer cell apoptosis and are potential targets for 
novel anticancer drugs that regulate the levels of deacetylated histone proteins, p53, and several transcriptional factors (Table 1) (Tae et al., 2018). 15d-PGJ 2 treatment significantly induced apoptosis rate, apoptosis-promoting protein expression, and reduced apoptosis-inhibiting protein expression in the hepatitis $B$ virus $(\mathrm{HBV}) \times$ protein $(\mathrm{HBx})$-positive HL7702-HBx and HL7702 liver cells (Chen et al., 2014).

\section{Anti-angiogenic/Anti-metastatic Actions}

15d-PGJ $\mathrm{J}_{2}$ exerts anti-angiogenic activity by inhibiting VEGF and angiopoietin-1 (Ang-1) in renal cancer (Yuan et al., 2005) and gastric cancer (Fu et al., 2006), respectively. Treatment of human umbilical vein endothelial cells (HUVEC) with 15d$\mathrm{PGJ}_{2}$ reduced mRNA levels of VEGF receptors 1 (Flt-1) and 2 (Flk/KDR) and urokinase plasminogen activator (uPA) and increased plasminogen activator inhibitor-1 (PAI-1) mRNA (Funovics et al., 2006). Administration of 15d-PGJ 2 could inhibit VEGF-induced angiogenesis in the rat cornea in a PPAR- $\gamma$ dependent manner (Xin et al., 1999) (Table 1). Rosiglitazone (Avandia) and troglitazone (TGZ) inhibit cell migration via the upregulation of E-cadherin expression in HepG2 cells (Lee et al., 2009). 15d-PGJ 2 inhibits NF- $\kappa B$ and AP-1-mediated MMP-9 expression and invasion of MCF-7 breast cancer cells employing a heme oxygenase-1 (HO-1)-dependent mechanism (Jang et al., 2020). Treatment with a low concentration of $15 \mathrm{~d}-\mathrm{PGJ}_{2}$ disassembled focal adhesions, reduced focal adhesion kinase (FAK) phosphorylation, and caused extensive filamentous actin reorganization (Yamamoto et al., 2020). PPAR- $\gamma$ did not mediate the inhibitory effect of $15 \mathrm{~d}-\mathrm{PGJ} \mathrm{J}_{2}$ on the migration of Caki-2 cells and did not affect RCC metastasis (Yamamoto et al., 2020).

\section{Antioxidant and Resolving Actions}

Inflammation is accompanied by the production of ROS, and $15 \mathrm{~d}-\mathrm{PGJ}_{2}$ has antioxidant properties (Itoh et al., 2004; Levonen et al., 2004; Mochizuki et al., 2005) (Table 1). $15 \mathrm{~d}-\mathrm{PGJ} \mathrm{J}_{2}$ and structurally related isoprostanoids alkylate Kelch-like ECH-associated protein 1 (Keap1) to induce the NF-E2-related nuclear factor erythroid-2 (Nrf2-) dependent antioxidant bioactivity (Levonen et al., 2004; Kansanen et al., 2009; Diers et al., 2010; Mills et al., 2018). 15d-PGJ 2 activates Nrf2-Keap1 signaling and induces gene transcription of antioxidant enzymes including $\mathrm{HO}-1$, superoxide dismutase (SOD), catalase, NAD(P)H dehydrogenase quinone 1 (NQO1), c-glutamylcysteine synthetase (GCS), glutathione reductase (GR), and glutathione peroxidase 1 (GPx) (Itoh et al., 2004; Kansanen et al., 2009; Diers et al., 2010; Magesh et al., 2012). 15d-PGJ 2 upregulates 15-hydroxyprostaglandin dehydrogenase (15-PGDH) gene expression, protein level, and its activity in human colon cancer cell line HCT-116 through AP-1 activation (Park and Na, 2019a,b). 15d-PGJ 2 treatment-induces eIF2 $\alpha$ phosphorylation and activation of the integrated stress response (ISR), also leading to bulk translation repression and preferential translation of stress response mRNAs (Tauber and Parker, 2019). $15 \mathrm{~d}-\mathrm{PGJ} \mathrm{J}_{2}$ is pro-resolving signaling and a neuroprotective (Rajan et al., 2020) molecule (Table 1) (Rajakariar et al., 2007; Niro et al., 2010; Flores et al., 2016; Coutinho et al., 2017).

\section{Pro-metastatic Properties of the Cyclopenenone Prostaglandins}

cyPGs also exhibit pro-metastatic properties such as $15 \mathrm{~d}-\mathrm{PGJ}_{2}$ significantly enhanced the rate of formation, the size, and the vascularization of papillomas in a murine carcinogenesis model (Millan et al., 2006). 15d-PGJ 2 and $\mathrm{PGJ}_{2}$ induced the proliferation of COX-2 depleted colorectal cancer (HCA-7) cells at a nanomolar concentration (Chinery et al., 1999). However, the precise mechanisms responsible for tumor proliferative effects of $15 \mathrm{~d}-\mathrm{PGJ}_{2}$ remain incompletely clarified. VEGF is well known as a master regulator of angiogenic switch (Bussolati and Mason, 2006). Interestingly, VEGF upregulates HO-1 in vascular endothelial cells, while HO-1 may also regulate the synthesis and activity of VEGF, thus constituting a positive feedback loop (Bussolati and Mason, 2006). 15d-PGJ 2 could stimulate VEGF expression in endothelial cells, human androgen-independent PC3 prostate cancer cells, and the 5,637 urinary bladder carcinoma cell line (Yamakawa et al., 2000; Haslmayer et al., 2002). The upregulation of VEGF by $15 \mathrm{~d}-\mathrm{PGJ}_{2}$ was accompanied by activation of PPAR- $\gamma$ (Jozkowicz et al., 2002). However, the VEGF promoter does not harbor PPRE (Inoue et al., 2001; Jozkowicz et al., 2004). Interestingly, VEGF upregulation by $15 d-$ $\mathrm{PGJ}_{2}$ could be mimicked by the induction of HO-1 expression (Jozkowicz et al., 2004). 15d-PGJ 2 induced HO-1 expression in MCF-7 human breast cancer cells (Kim et al., 2004).

$\mathrm{Nrf2}$, a transcription factor is responsible for maintenance of cellular redox balance (Loboda et al., 2016). HO-1 is a prototypic $\mathrm{Nrf} 2$ target gene, and the aberrant hyperactivation of $\mathrm{Nrf} 2 / \mathrm{HO}-$ 1 axis contributes to tumor progression, aggressiveness, chemoresistance, and poor prognosis (Zimta et al., 2019). $15 \mathrm{~d}-\mathrm{PGJ}_{2}$ induces VEGF expression and angiogenesis in human breast cancer cells through upregulation of HO-1 (Kim et al., 2006; Kweider et al., 2011).

\section{ROLE OF CYCLOPENTENONE PROSTAGLANDINS DURING VIRAL INFECTIONS}

\section{Cyclopentenone Prostaglandins as Inhibitor of Viral Replication}

cyPGs are potent inhibitors of viral replication (Table 2) and are effective against a wide range of viruses. These include negativestrand RNA viruses such as influenza A (Pica et al., 1993, 2000; Conti et al., 2001), Sendai virus (Amici and Santoro, 1991; Amici et al., 2001), and vesicular stomatitis virus (VSV) (Santoro et al., 1987; Pica et al., 1993); positive-strand RNA viruses such as Sindbis virus (Mastromarino et al., 1993), Poliovirus (Conti et al., 1996), and Human immunodeficiency virus-1 (Rozera et al., 1996) and DNA viruses such as herpes simplex virus (HSV) type 1 and 2 (Yamamoto et al., 1987; Amici et al., 2001). The ability of cyPGs to suppress virus production is very dramatic. In the African green monkey kidney (AGMK) cell line, replication of the Sendai virus is almost completely inhibited by $4 \mathrm{mg} / \mathrm{ml}$ of PGA $_{1}$ (Santoro et al., 1987) and by $4 \mathrm{mg} / \mathrm{ml}$ of $\mathrm{PGJ}_{2}$ (Santoro et al., 1987) without being toxic to uninfected 
TABLE 2 | Effects of cyclopentenone prostaglandins in viral infections.

\begin{tabular}{|c|c|c|c|c|}
\hline Anti-viral Activity & Virus & CyPGs & Mechanism & References \\
\hline \multirow{7}{*}{$\begin{array}{l}\text { Inhibition of virus replication } \\
\text { by altering viral gene/protein } \\
\text { expression } \\
\text { (transcription/translation } \\
\text { level alteration) }\end{array}$} & Influenza A & $\Delta^{12}-P G J_{2}$ & $\begin{array}{l}\text { Decrease synthesis of hemagglutinin }(\mathrm{HA}) \text {, nucleoprotein } \\
\text { (NP), and membrane protein M1; induction of } 70 \mathrm{kDa} \text { host } \\
\text { HSP70 }\end{array}$ & Pica et al., 1993 \\
\hline & & $\mathrm{PGA}_{1}$ & $\begin{array}{l}\text { Delayed synthesis of HA, membrane protein M1, structural } \\
\text { protein M2, and non-structural protein NS2; induction of } \\
70 \mathrm{kDa} \text { host HSP70 }\end{array}$ & Conti et al., 2001 \\
\hline & $\begin{array}{l}\text { Vesicular Stomatitis } \\
\text { Virus (VSV) }\end{array}$ & $\Delta^{12}-P G J_{2}, P G A_{1}$ & Inhibit VSV RNA polymerase & $\begin{array}{l}\text { Bader and Ankel, 1990; } \\
\text { Pica et al., 1993; } \\
\text { Parker, } 1995\end{array}$ \\
\hline & $\begin{array}{l}\text { Herpes Simplex Virus } \\
\text { Type } 1 \text { (HSV-1) }\end{array}$ & $\mathrm{PGA}_{1}$ & $\begin{array}{l}\text { Suppress NF-кB activation by inhibiting IKK complex } \\
\text { (independent of the PPAR- } \gamma \text { pathway) }\end{array}$ & Amici et al., 2001 \\
\hline & $\begin{array}{l}\text { Herpes Simplex Virus } \\
\text { Type } 2 \text { (HSV-2) }\end{array}$ & $\Delta 7-\mathrm{PGA}_{1}, \Delta^{12}-\mathrm{PGJ}_{2}$ & Inhibited the primary transcription of HSV-2 & Yamamoto et al., 1987 \\
\hline & $\begin{array}{l}\text { Human } \\
\text { Immunodeficiency } \\
\text { Virus-1 (HIV-1) }\end{array}$ & $\mathrm{PGJ}_{2}$ & $\begin{array}{l}\text { Suppress NF-кB activation by inhibiting IKK complex } \\
\text { (independent of the PPAR- } \gamma \text { pathway) }\end{array}$ & $\begin{array}{l}\text { Rozera et al., 1996; } \\
\text { Boisvert et al., } 2008\end{array}$ \\
\hline & & $15 d-P G J_{2}$ & $\begin{array}{l}\text { Covalently modify HIV-1 transactivating protein, Tat to } \\
\text { inhibit virus transcriptional elongation }\end{array}$ & Kalantari et al., 2009 \\
\hline \multirow{2}{*}{$\begin{array}{l}\text { Inhibition of virus replication } \\
\text { by altering viral glycoprotein } \\
\text { glycosylation } \\
\text { (post-translational level } \\
\text { alteration) }\end{array}$} & $\begin{array}{l}\text { Vesicular Stomatitis } \\
\text { Virus (VSV) }\end{array}$ & $\Delta^{12}-\mathrm{PGJ} J_{2}$ & Inhibit glycosylation of virus glycoprotein G & Pica et al., 1993 \\
\hline & Sendai Virus & $P G A_{1}, \Delta^{12}-P G J_{2}$ & $\begin{array}{l}\text { Inhibit glycosylation of virus glycoproteins } \\
\text { hemagglutinin-neuraminidase }(H N) \text { and fusion protein }(F)\end{array}$ & $\begin{array}{l}\text { Santoro et al., 1987; } \\
\text { Amici et al., } 2001\end{array}$ \\
\hline $\begin{array}{l}\text { Inhibition of virus cell-to-cell } \\
\text { transmission }\end{array}$ & $\begin{array}{l}\text { Human T-cell Leukemia } \\
\text { Virus Type I (HTLV-1) }\end{array}$ & $P G A_{1}, P G J_{2}$ & $\begin{array}{l}\text { Inhibit host cell proliferation by inducing cell arrest at the } \\
\text { G1/S interface }\end{array}$ & $\begin{array}{l}\text { D'Onofrio et al., 1992; } \\
\text { Lacal et al., 1994a,b }\end{array}$ \\
\hline \multirow[t]{4}{*}{$\begin{array}{l}\text { Inhibition of virus-induced } \\
\text { inflammation }\end{array}$} & Influenza & $15 d-P G J_{2}$ & $\begin{array}{l}\text { Decrease virus-induced release of proinflammatory } \\
\text { cytokines (IL-6, TNF- } \alpha \text { ) and chemokines (CCL2, CCL3, } \\
\text { CCL4, and CXCL10) via PPAR- } \gamma \text { pathway }\end{array}$ & Cloutier et al., 2012 \\
\hline & $\begin{array}{l}\text { Respiratory Syncytial } \\
\text { Virus (RSV) }\end{array}$ & $15 d-P G J_{2}$ & $\begin{array}{l}\text { Decrease virus-induced release of cytokines (TNF- } \alpha \text {, } \\
\text { GMCSF, IL-1 } \alpha, I L-6) \text {, and the chemokines (CXCL8 (IL-8) } \\
\text { and CCL5) via PPAR- } \gamma \text { pathway. Reduce immune cells } \\
\text { adhesion by inhibiting virus-induced up-regulation of } \\
\text { intercellular adhesion molecule-1 (ICAM1). Reduce activity } \\
\text { of inflammatory pathway, NF-кB. }\end{array}$ & Arnold et al., 2007 \\
\hline & $\begin{array}{l}\text { Human } \\
\text { Immunodeficiency } \\
\text { Virus-1 (HIV-1) }\end{array}$ & $15 d-P G J_{2}$ & Suppress NF-кB activation by inhibiting IKK complex & Boisvert et al., 2008 \\
\hline & Zika virus (ZIKV) & $15 d-P G J_{2}$ & $\begin{array}{l}\text { Control brain inflammation by downregulating microglial } \\
\text { activation and by inducing apoptosis of activated microglia }\end{array}$ & $\begin{array}{l}\text { Bernardo and } \\
\text { Minghetti, } 2006\end{array}$ \\
\hline
\end{tabular}

AGMK cells. Treatment of $6 \mathrm{mg} / \mathrm{ml}$ of $\Delta^{12}-\mathrm{PGJ}_{2}$ in MadinDarby canine kidney cells (MDCK) infected with influenza A H1N1 (PR8) virus drastically suppressed the viral production by $95 \%$. Simultaneously, a higher dose of $\Delta^{12}-\mathrm{PGJ}_{2}$ produced an undetectable virus yield (Pica et al., 1993). PGA 1 treatment also strongly inhibits the viral production of Ulster $73(\mathrm{H} 7 \mathrm{~N} 1$ influenza A) in LLC-monkey kidney epithelial cells (LLC-MK2), African green monkey kidney-37RC cells (AGMK-37RC), and MDCK cells (Conti et al., 2001), suggesting that cyPGs are effective against various subtypes of influenza $\mathrm{A}$ virus in multiple host cells. Similarly, in vivo studies have shown that $\mathrm{PGA}_{1}$ and 16,16 -dimethyl-PGA 2 (dmPGA $\left.{ }_{2}\right)$, a long-acting synthetic analog of PGA, in mice infected with a lethal dose of PR8 virus significantly decreases the virus titers in the lung and increases the survival rate (Santoro et al., 1987; Pica et al., 1993). In another study, the antiviral activity of the synthetic dmPGA 1 in HSV-1 and human immunodeficiency virus (HIV)- infected cells was investigated (Hughes-Fulford et al., 1992). dmPGA 1 affected HIV-1 replication in acutely infected $\mathrm{T}$ cells and chronically infected macrophages as assessed by a quantitative decrease in HIV-1 antigen p24 concentration (Hughes-Fulford et al., 1992). This study highlighted the unusual broad-spectrum antiviral activity of dmPGA 1 against HSV and HIV-1 and its therapeutic potential for in vivo use (Hughes-Fulford et al., 1992).

Depending on the virus, cyPGs utilize various mechanisms and act on different viral cycle events to interfere with virus production. In HIV-1 infection and avian influenza, A virus infection, cyPGs prevent very early virus infection phases such 
as viral adsorption and penetration into target cells (Rozera et al., 1996; Carta et al., 2014). Even though antiviral action mechanisms differ between various viruses and host cell systems, the inhibition of virus replication by cyPGs is often associated with (1) alteration in viral protein synthesis and (2) alteration in viral glycoprotein glycosylation (Table 2). $\mathrm{PGA}_{1}$ treatment inhibited replication of Mayaro virus (MAYV) (an arbovirus endemic to certain humid forests of tropical South America) by $95 \%$ at $24 \mathrm{~h}$ post-infection in human epithelial type 2 (Hep2) cells (Caldas et al., 2018). PGA 1 treatment inhibited viral structural protein synthesis by $15 \%$, possibly via heat shock protein70 (HSP70) induction (Caldas et al., 2018).

\section{Cyclopentenone Prostaglandins Alter Viral Protein Synthesis}

Inhibition of individual virus replication by cyPGs is marked by dysregulation of viral protein synthesis (Table 2). In influenza, A PR8 virus (a mouse-adapted $\mathrm{H} 1 \mathrm{~N} 1$ influenza virus causing severe infection in mice)-infected cells, treatment of $\Delta^{12}-\mathrm{PGJ}_{2}$ substantially decreased the synthesis of PR8 proteins such as hemagglutinin (HA), nucleoprotein (NP), and membrane protein M1 (Pica et al., 1993). PGA 1 could cause a significant delay in the synthesis of late viral polypeptides: HA, membrane protein M1, structural protein M2, and non-structural protein NS2 (Conti et al., 2001). Furthermore, both studies showed that inhibition or delay of viral protein synthesis is accompanied by induction of a $70 \mathrm{kDa}$ host polypeptide identified as HSP70 by immunoblot analysis (Pica et al., 1993; Conti et al., 2001). Because viral protein synthesis is repressed as long as HSP70 is present in the host cell, HSP70 seems to play an essential role in cyPGs antiviral activity.

In VSV infection, $\Delta^{12}-\mathrm{PGJ}_{2}$ can affect two distinct stages (an early stage and a late-stage) of the virus replication cycle in epithelial monkey cell lines (Pica et al., 1993). The inhibition of the virus at the initial stage is associated with altered viral protein synthesis. When the cells are treated with $8 \mathrm{mg} / \mathrm{ml}$ of $\Delta^{12}-\mathrm{PGJ}_{2}$ soon after virus infection, there is a dramatic decrease in VSV protein synthesis. Similar to the effect on influenza A virus replication, inhibition of VSV protein synthesis by $\Delta^{12}$ $\mathrm{PGJ}_{2}$ is also associated with the induction of a $74 \mathrm{kDa}$ polypeptide belonging to the group of heat shock protein HSP70 (Pica et al., 1993). In another study, $\mathrm{PGA}_{1}$ treatment decreased VSV proteins' production and the amount of respective viral mRNA (Bader and Ankel, 1990). This study found that PGA 1 exerts its antiviral activity at the VSV genes' primary transcription level, which leads to a reduction in viral mRNA synthesis, viral protein synthesis, and, ultimately, viral replication. To further investigate the antiviral activity of cyPGs, another study performed an RNA polymerase assay and reported that cyPGs potently inhibit VSV RNA polymerase (Parker, 1995). This inhibition correlates with the decrease in VSV replication in infected cells, indicating that cyPGs antiviral activity is due to VSV RNA polymerase inhibition.

In addition to VSV, cyPGs also exert a transcriptional block in the replication of herpes simplex virus type 1 (HSV-1) (Amici et al., 2001), HSV-2 (Yamamoto et al., 1987), and HIV1 (Rozera et al., 1996). In HSV-1 infected human laryngeal carcinoma cells and neuroblastoma cells and HIV-1 infected colonic epithelial cells (caco-2 cells), cyPGs inhibit viral gene expression by suppressing NF- $\kappa \mathrm{B}$ activation, independent of the PPAR- $\gamma$ pathway (Amici et al., 2001; Boisvert et al., 2008). NF-кB is essential for many processes, including viral gene expression and, consequently, replication of viruses that contain NF- $\kappa B$ binding sites in their genomes. In its inactivated cytosolic form, $\mathrm{NF}-\kappa \mathrm{B}$ is bound to inhibitory I $\mathrm{B}$ proteins such as $\mathrm{I} \kappa \mathrm{B} \alpha$. Stimuli like bacterial and viral infections increase the activity of the IKK complex, which phosphorylates I $\mathrm{B} \alpha$, leading to ubiquitination

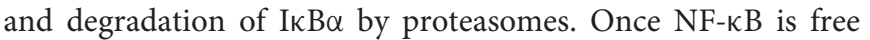
from I $\mathrm{B} \alpha$, it translocates into the cell nucleus, activating the transcription of many genes, including the viral genes of HSV-1 and HIV-1 (Amici et al., 2001; Boisvert et al., 2008). Amici et al. (2001) showed that PGA 1 significantly decreases the NF- $\mathrm{BB}$ induction in HSV-1 infected cells by inhibiting the IKK complex.

Similarly, another study reported that the administration of $\mathrm{PGJ}_{2}$ reduces IKK activity in $\mathrm{HIV}-1$ infected cells (Boisvert et al., 2008). In both cases, suppression of IKK activity by cyPGs prevents $\mathrm{I} \kappa \mathrm{B} \alpha$ degradation and NF- $\kappa \mathrm{B}$ translocation to the nucleus. As a result, viral gene transcription and protein synthesis were repressed, leading to a significant reduction in virus production. In addition to interfering with NF- $\mathrm{B}$ induction, cyPGs also target another pathway independent of NF$\kappa \mathrm{B}$ to inhibit HIV-1 replication. Kalantari et al. (2009) reported that $15 \mathrm{~d}-\mathrm{PGJ}_{2}$ represses $\mathrm{HIV}-1$ transcription by inhibiting HIV1 transactivating protein, Tat. While the host transcriptional factor NF- $\kappa \mathrm{B}$ binds to the $5^{\prime}$ long terminal repeat (LTR) of HIV-1 to initiate transcription, viral Tat protein is recruited to an RNA stem-loop structure called transactivation response element (TAR) and is necessary for transcriptional elongation. Tat then recruits transcription elongation factor $\mathrm{p}-\mathrm{TEFb}$, which transactivates HIV LTR and allows the RNA polymerase II to continue the transcription with high processivity. $15 \mathrm{~d}-\mathrm{PGJ}_{2}$ interferes with Tat-dependent transcriptional elongation by covalently modifying the thiol groups of Tat's cysteine residues (Kalantari et al., 2009). The resulting altered Tat protein is unable to transactivate HIV LTR in U937 human macrophages, inhibiting the transcription and replication of the virus.

\section{Cyclopentenone Prostaglandins Alter Viral Glycoprotein Glycosylation}

cyPGs can also inhibit viral replication at the post-translational level by altering the glycosylation of viral glycoproteins. This is seen in the VSV and Sendai virus (Table 2). As mentioned earlier, $\Delta^{12}-\mathrm{PGJ}_{2}$ inhibits the VSV replication in the epithelial monkey cell line at two stages of the virus replication cycle. The inhibition at the early stage is due to a block in viral protein synthesis. Administration of $\Delta^{12}-\mathrm{PGJ}_{2}$ at a later stage (6-8 h post-infection) also leads to a decrease in virus production even though viral protein synthesis should have been completed by that time (Pica et al., 1993). $\Delta^{12}-\mathrm{PGJ}_{2}$ treatment started at a later stage does not affect viral protein synthesis, but it drastically decreases the glucosamine incorporation into the virus glycoprotein $\mathrm{G}$ without altering most cellular proteins. 
Similarly, $\mathrm{PGA}_{1}$ treatment in AGMK cells infected with the Sendai virus results in inhibition of glycosylation of viral glycoproteins hemagglutinin-neuraminidase (HN) and fusion protein $(\mathrm{F})$, as indicated by the decrease in glucosamine incorporation (Santoro et al., 1987). The synthesis of nonglycosylated viral polypeptides of RNA transcriptase complex, including proteins $\mathrm{P}, \mathrm{NP}$, and matrix protein $(\mathrm{M})$, are not affected by $\mathrm{PGA}_{1}$ treatment. Likewise, $\Delta^{12}-\mathrm{PGJ}_{2}$ also markedly reduces the incorporation of glucosamine into $\mathrm{HN}$ and $\mathrm{F}$ viral glycoproteins without inhibiting the synthesis of cellular or viral proteins (Amici et al., 2001). The altered HN glycoprotein cannot insert into the cell membrane, which leads to an inhibition of virus maturation and production.

\section{The Effect of Cyclopentenone Prostaglandins on Viral Transmission}

cyPGs can interfere with virus transmission via their antiproliferative activity. When $\mathrm{PGA}_{1}$ and $\mathrm{PGJ}_{2}$ are given to human T-cell leukemia virus type-I (HTLV-1) producing MT2 cell line, they inhibit the growth of the cells in a dose-dependent manner (D'Onofrio et al., 1992). These cyPGs cause the cells to be arrested at the G1/S interface without detectable cellular toxicity. Another study showed that $\mathrm{PGA}_{1}$ and $\mathrm{PG}_{2}$ inhibit the proliferation of myeloid cells (K562 pluripotent stem cells, HL60 promyelocytic cells, and U937 monoblastoid cells) during early infection of HTLV-1, also in a dose-dependent manner (Lacal et al., 1994a,b). Furthermore, out of the three myeloid cell lines used in the study, the effect of growth inhibition is highest in U937 monoblastoid cells, followed by HL60 promyelocytic cells, and then K562 pluripotent stem cells. This suggests that cyPGs have a more significant antiproliferative effect on differentiated cells.

The primary mode of infection of HTLV-1 is cell-tocell transmission (Yoshida and Seiki, 1987). Furthermore, for retrovirus-like HTLV-1, integration of proviral DNA occurs after the initiation of cellular DNA synthesis in dividing cells (Varmus et al., 1979). Thus, alterations in cell proliferation and cell cycle can affect the permissiveness of recipient cells to HTLV-1. Indeed, in U937 monoblastoid cells co-cultured with virus-donor cells, $\mathrm{PGA}_{1}$ and $\mathrm{PGJ}_{2}$ treatments reduce the transmission of HTLV1 (Lacal et al., 1994a,b). However, in less differentiated K562 pluripotent stem cells and HL60 promyelocytic cells, infection of recipient cells increased after cyPGs treatment antiproliferative activity is observed in these cells. This suggests that the effect of cyPGs on virus transmission is affected by cell differentiation.

\section{The Effect of Cyclopentenone Prostaglandins on Viral Infection Induced Inflammation}

Viral infections such as influenza virus, HIV-1, and respiratory syncytial virus (RSV) are characterized by excessive inflammation with the upregulation of proinflammatory cytokines and chemokines. The amount of these proinflammatory molecules correlates with the severity of illness (Griffin et al., 1994; Wesselingh et al., 1994; Hornsleth et al., 2001; Welliver et al., 2002). Given the anti-inflammatory effects of cyPGs, studies have been done to explore the possibility of utilizing cyPGs as a therapeutic agent for viral infections. In mice infected with lethal influenza infection, administration of $15 \mathrm{~d}-\mathrm{PGJ}_{2}$ 1 day after infection resulted in reduced influenza morbidity and mortality, accompanied by substantially decreased gene expression of proinflammatory cytokines (IL-6 and TNF$\alpha)$ and chemokines (CCL2, CCL3, CCL4, and CXCL10) via activation of PPAR- $\gamma$ pathway (Cloutier et al., 2012). Similarly, $15 \mathrm{~d}-\mathrm{PGJ}_{2}$ and other PPAR- $\gamma$ agonists (ciglitazone and TGZ) can inhibit the RSV-induced release of cytokines TNF- $\alpha$, GMCSF, IL- $1 \alpha$, IL-6, and the chemokines CXCL8 (IL-8) and CCL5 (Arnold et al., 2007). Moreover, RSV infection of the human airway epithelial cells causes an increase in expression of intercellular adhesion molecule-1 (ICAM1) on the cell surface, which enhances the adhesion of recruited immune effector cells, contributing to an intense inflammatory response and increased cytotoxicity (Wang et al., 2000; Arnold et al., 2007). Treatment of $15 d-\mathrm{PGJ}_{2}$ and other PPAR- $\gamma$ agonists results in inhibition of the upregulation of ICAM1, with the reduced cellular amount of ICAM1 mRNA (Arnold et al., 2007). This leads to a significant reduction in the adhesion of immune cells to RSV-infected cells. Also, the $15 \mathrm{~d}_{-} \mathrm{PGJ}_{2}$ treatment in RSVinfected cells is associated with reduced activity of $N F-\kappa B$, a transcription factor essential for inflammatory responses. In HIV-infected intestinal epithelial cells, 15d-PGJ 2 also reduces the nuclear translocation of NF- $\mathrm{B}$ and represses $\mathrm{HIV}-1$ transcription by decreasing the activity of IKK (Boisvert et al., 2008). Overall, cyPGs can reduce the exaggerated inflammatory response associated with viral infections and great therapeutic value. $\mathrm{PGD}_{2} / \mathrm{DP} 1$ axis and $15 \mathrm{~d}-\mathrm{PGJ}_{2}$ signaling contributes to the regulation of the CNS-specific response to pathogens such as neurotropic coronavirus (CoV) (Vijay et al., 2017) and acute encephalitis (Rosenberger et al., 2004), chronic demyelinating encephalomyelitis causing neurotropic virus called "MHV" (mouse hepatitis virus strain JHM) (Zheng et al., 2020).

Zika virus (ZIKV), one of the most medically relevant viral infections, affects the developing brain during pregnancy, and its connection with congenital malformations/microcephaly is well documented (de Oliveira et al., 2019). Neuroinflammation is one of the critical factors contributing to ZIKV-related microcephaly, inflammatory processes mediated by glial cells (Wen et al., 2017; Huan et al., 2018). $\mathrm{PGD}_{2}, \mathrm{PGE}_{1}, \mathrm{PGE}_{2}$, and $\mathrm{PGI}_{2}$ have been correlated with neuroinflammation, protecting the CNS, and physiological responses to minimize further damage to neural tissue. Their anti-inflammatory reaction has been demonstrated in neuronal injuries (Shi et al., 2010) and neuroprotection during acute brain injury (Liang et al., 2005; An et al., 2014) 15d-PGJ 2 activates PPAR- $\gamma$ by downregulating microglial activation despite the proinflammatory environment because of the neural damage (Bernardo and Minghetti, 2006).

$15 \mathrm{~d}-\mathrm{PGJ}_{2}$ has demonstrated beneficial effects in the severe diseases arising from bacterial infections of Staphylococcus aureus (Phulwani et al., 2006), Salmonella enterica Typhimurium (Buckner et al., 2013), leading to brain abscess, typhoid fever, gastroenteritis, and protozoan hemoflagellate Trypanosoma 
brucei infection-causing sleeping sickness in humans (Figarella et al., 2006).

\section{OTHER ALPHA, BETA-UNSATURATED CARBONYL LIPIDS AND CYCLOPENTENONE ISOPROSTANES}

There is another category of highly reactive electrophilic molecules, which react and modify both proteins and DNA resulting in toxicity, protein dysfunction (Sayre et al., 2006) or tissue damage and disease progression (Lee and Park, 2013). These are $\alpha, \beta$-unsaturated aldehydes such as acrolein (ACR), 4hydroxy-2-non-enal (4-HNE), and crotonaldehyde (CRA) are the most reactive and toxic $\alpha, \beta$-unsaturated aldehydes (Lee and Park, 2013).These induce toxicity because of depletion of cellular GSH and inactivation of antioxidant enzymes (GPx and thioredoxin; TRx) subsequently leading to ROS production, reactive nitrogen species (RNS), and free radicals (Stocker and Keaney, 2004; Lee and Park, 2013). Lipid peroxidation (LPO)-derived $\alpha, \beta$ unsaturated aldehydes play an important pathophysiological role in vascular diseases by inducing the production of various atherogenic factors, inflammatory mediators, activation of NF- $\kappa \mathrm{B}$ signaling pathway, redox signaling mediators leading to cellular and tissue injury (Lee and Park, 2013).

Isoprostanes (IsoPs) are PG-like compounds that are produced in vivo independently of COX enzymes, primarily by ROS-mediated or free radical-induced peroxidation of arachidonic acid (Stamatakis and Perez-Sala, 2006). IsoPs along with cyPGs are reactive electrophilic eicosanoids that can form covalent adducts with thiol-containing molecules, cysteine residues in proteins through Michael addition (Stamatakis and Perez-Sala, 2006). Oxidation of DHA in the central nervous system, results in the formation of IsoP-like compounds, termed neuroprostanes and are uniquely valuable to understanding the clinical pharmacology of antioxidants (Montuschi et al., 2007). Cyclopentenone IsoPs are formed abundantly in brain tissue under conditions of oxidative stress (glutathione depletion, ROS generation, activation of redox-sensitive signaling pathways) and may contribute to neuronal death causing neurodegeneration and should be addressed when designing neuroprotective therapies (Musiek et al., 2006, 2007; Porta et al., 2013). IsoPs are measured in the plasma, urine, or cerebral spinal fluid (CSF) and their increase has been observed in obese adults (Morrow, 2005; Basu, 2008), ischemia-reperfusion (Sakamoto et al., 2002; Rossi et al., 2004), Alzheimer's disease (AD) (Montine et al., 1998, 1999a; Pratico et al., 1998, 2000), Huntington's disease (Montine et al., 1999b), Parkinson's disease (Fessel et al., 2003; Seet et al., 2010), and amyotrophic lateral sclerosis (ALS) (D'Amico et al., 2013). Few studies have investigated the associations between levels of F2-IsoPs and risk of breast cancer (Rossner et al., 2006), hepatocellular carcinoma (Wu et al., 2008), prostate cancer (Barocas et al., 2011; Brys et al., 2013) gastric cancer (Asombang et al., 2013). IsoPs are increased in patients with genetic disorders such as autism-spectrum disorders (Ming et al., 2005; Gorrindo et al., 2013), Smith-Lemli-Opitz Syndrome (SLOS) (Korade et al., 2013), sickle cell anemia (Akohoue et al., 2007), cystic fibrosis (Collins et al., 1999; Ciabattoni et al., 2000; Montuschi et al., 2000), Rett syndrome (RTT) (De Felice et al., 2009, 2011; Signorini et al., 2011; Durand et al., 2013), and in various inborn errors of metabolism (Mc Guire et al., 2009).

\section{SUMMARY AND FUTURE DIRECTIONS}

There is significant evidence that cyPGs $\left(\mathrm{PGA}_{1}, \mathrm{PGA}_{2}\right.$, and $\left.\mathrm{PGJ}_{2}\right)$, and metabolites of $\mathrm{PGJ}_{2}\left(15 \mathrm{~d}-\mathrm{PGJ}_{2}\right.$ and $\left.\Delta^{12}-\mathrm{PGJ}_{2}\right)$ can induce anti-inflammatory and antiviral effects through covalent modification reactions with their $\alpha, \beta$-unsaturated carbonyl group. cyPGs can exert anti-inflammatory and antiviral effects in various ways depending on the host cell and pathogen type. Cell type is not the only influencer on the anti-inflammatory effects of cyPGs. The concentration of cyPGs and the length/time of exposure to cyPGs have varying anti-inflammatory and antiviral effects. Based on these factors, cyPGs can show biphasic targeting of inflammation (Garzon et al., 2011). At high doses, $15 \mathrm{~d}-\mathrm{PGJ}_{2}$ has a dual action of stimulating anti-inflammation and anti-proliferation. Still, it can be toxic and induce both inflammation and cell proliferation at lower doses, and the biphasic pharmacodynamics has to be controlled carefully (Abbasi et al., 2016). Dose-related efficacy and safety of oral $\mathrm{DP}_{2}$ receptor antagonists fevipiprant (QAW039), timapriprant (OC000459), and BI 671800 have been tested in patients with allergic asthma and $\mathrm{COPD}$, and $\mathrm{PGD}_{2}$ has shown anticancer effects in NSCLC (non-small cell lung carcinoma), kidney and lung fibrosis, and gastric cancer (Bateman Guerreros et al., 2017; Jandl and Heinemann, 2017; Pearson et al., 2017; Sandham et al., 2017a,b; Murillo et al., 2018; Brightling et al., 2020). Further research on outcomes based on specific concentrations is warranted. PPAR- $\gamma$ antagonist (GW9662) and PPAR- $\gamma$ ligands are new therapeutic targets in sepsis, hemorrhagic shock, and inflammation (Kaplan et al., 2005, 2010; Zingarelli and Cook, 2005; Chima et al., 2011). Synthetic PPAR- $\gamma$ ligands rosiglitazone (Avandia) and pioglitazone have exhibited anti-inflammatory and antiviral effects in an EcoHIV mouse model that could decrease neurodegeneration. These drugs prove promising in treating HIV-1 associated neurocognitive disorders (Omeragic et al., 2020). This knowledge could significantly impact how viruses and inflammation can be treated.

The outcome of the $15 \mathrm{~d}-\mathrm{PGJ}_{2}$ treatment depends upon its exogenously administered dose as it stimulates antiinflammation and anti-proliferation at high doses while can have toxic effects at a lower dose (Abbasi et al., 2016). Many strategies have been developed to deal with the biphasic pharmacodynamics of $15 \mathrm{~d}-\mathrm{PGJ}_{2}$ and one of them is using a nanoemulsion (NE) composed of triolein/distearoyl phosphatidylcholine/Tween 80 at a high encapsulation ratio (>83\%) allowing slow-release kinetics (Abbasi et al., 2016). NE retained a high proportion of $15 \mathrm{~d}-\mathrm{PGJ}_{2}$ and directly delivered it to the cytosol, where proapoptotic targets are located, and could bypass cell membrane-associated targets involved in cell proliferation (Abbasi et al., 2016). NE could deliver 15d-PGJ 2 to its desired site of action, excluding undesired sites, on a subcellular level (Abbasi et al., 2016) and could be used as 
one of the strategies for treatment. Since the use of solid lipid nanoparticles (SLN) can improve therapeutic properties by increasing drug efficiency and availability, $15 \mathrm{~d}-\mathrm{PGJ}_{2}-\mathrm{SLN}$ was developed and tested for its immunomodulatory potential. The $15 \mathrm{~d}-\mathrm{PGJ}_{2}$-SLN formulation showed good colloidal parameters, encapsulation efficiency (96\%), and stability (up to 120 days) with low hemolytic effects as compared to unloaded SLN in in vivo experiments. The $15 \mathrm{~d}-\mathrm{PGJ}_{2}-\mathrm{SLN}$ formulation using low concentrations reduced neutrophil migration in three inflammation models tested. 15d-PGJ 2 -SLN increased IL-10 levels and reduced IL-1 $\beta$ as well as IL-17 in peritoneal fluid thus highlighting the perspectives of a potent antiinflammatory system (de Melo et al., 2016). cyPGs have a wide spectrum of intracellular targets ranging from nuclear factors to mitochondria. Introduction of cyclopentenone moiety into molecules (jasmonates and chalcones) boosts their anticancer potential (Conti, 2006). Despite advancements made in the pharmacodynamics of cyPGs, a significant effort is needed to explore their unique therapeutic properties and tailor them to be used as leading anti-inflammatory, anticancer, and antiviral drugs.

\section{REFERENCES}

Abbasi, S., Kajimoto, K., and Harashima, H. (2016). Elimination of the biphasic pharmacodynamics of $15 \mathrm{~d}-\mathrm{PGJ} 2$ by controlling its release from a nanoemulsion. Int. J. Nanomed. 11, 2685-2694. doi: 10.2147/ijn.s106297

Akohoue, S. A., Shankar, S., Milne, G. L., Morrow, J., Chen, K. Y., Ajayi, W. U., et al. (2007). Energy expenditure, inflammation, and oxidative stress in steady-state adolescents with sickle cell anemia. Pediatr. Res. 61, 233-238. doi: 10.1203/pdr. 0b013e31802d7754

Amici, C., and Santoro, M. G. (1991). Suppression of virus replication by prostaglandin A is associated with heat shock protein synthesis. J. Gen. Virol. 72(Pt 8), 1877-1885. doi: 10.1099/0022-1317-72-8-1877

Amici, C., Belardo, G., Rossi, A., and Santoro, M. G. (2001). Activation of I kappa b kinase by herpes simplex virus type 1 . A novel target for anti-herpetic therapy. J. Biol. Chem. 276, 28759-28766.

An, Y., Belevych, N., Wang, Y., Zhang, H., Nasse, J. S., Herschman, H., et al. (2014). Prostacyclin mediates endothelial COX-2-dependent neuroprotective effects during excitotoxic brain injury. J. Inflamm. Res. 7, 57-67. doi: 10.2147/ jir.s63205

Aoki, T., and Narumiya, S. (2012). Prostaglandins and chronic inflammation. Trends Pharmacol. Sci. 33, 304-311.

Appel, S., Mirakaj, V., Bringmann, A., Weck, M. M., Grunebach, F., and Brossart, P. P. P. A. R. - (2005). gamma agonists inhibit toll-like receptor-mediated activation of dendritic cells via the MAP kinase and NF-kappaB pathways. Blood 106, 3888-3894. doi: 10.1182/blood-2004-12-4709

Arnold, R., Neumann, M., and Konig, W. (2007). Peroxisome proliferator-activated receptor-gamma agonists inhibit respiratory syncytial virus-induced expression of intercellular adhesion molecule-1 in human lung epithelial cells. Immunology 121, 71-81. doi: 10.1111/j.1365-2567.2006.02539.x

Asombang, A. W., Kayamba, V., Mwanza-Lisulo, M., Colditz, G., Mudenda, V., Yarasheski, K., et al. (2013). Gastric cancer in Zambian adults: a prospective case-control study that assessed dietary intake and antioxidant status by using urinary isoprostane excretion. Am. J. Clin. Nutr. 97, 1029-1035. doi: 10.3945/ ajcn.112.051284

Bader, T., and Ankel, H. (1990). Inhibition of primary transcription of vesicular stomatitis virus by prostaglandin A1. J. Gen. Virol. 71(Pt 12), 2823-2832. doi: 10.1099/0022-1317-71-12-2823

Barocas, D. A., Motley, S., Cookson, M. S., Chang, S. S., Penson, D. F., Dai, Q., et al. (2011). Oxidative stress measured by urine F2-isoprostane level is associated with prostate cancer. J. Urol. 185, 2102-2107. doi: 10.1016/j.juro.2011.02.020

\section{AUTHOR CONTRIBUTIONS}

All authors listed have made a substantial, direct and intellectual contribution to the work, and approved it for publication.

\section{FUNDING}

We are grateful for funding support from the Center for Cancer Cell Biology, Immunology and Infection and NIH-funded grant R01CA 192970 to NS-W. The funders had no role in the design, decision to publish, or preparation of the manuscript.

\section{ACKNOWLEDGMENTS}

All authors contributed equally to the article and approved the submitted version. NS-W apologizes to all the colleagues whose work could not be cited in this manuscript.

Basu, S. (2008). F2-isoprostanes in human health and diseases: from molecular mechanisms to clinical implications. Antioxid Redox Signal. 10, 1405-1434. doi: 10.1089/ars.2007.1956

Bateman Guerreros, A. G., Brockhaus, F., Holzhauer, B., Pethe, A., Kay, R. A.. (2017). Fevipiprant, an oral prostaglandin DP2 receptor (CRTh2) antagonist, in allergic asthma uncontrolled on low-dose inhaled corticosteroids. Eur. Respir. J. 50:2.

Bell-Parikh, L. C., Ide, T., Lawson, J. A., McNamara, P., Reilly, M., and FitzGerald, G. A. (2003). Biosynthesis of 15-deoxy-delta12,14-PGJ2 and the ligation of PPARgamma. J. Clin. Invest. 112, 945-955. doi: 10.1172/jci200318012

Bernardo, A., and Minghetti, L. P. P. A. R. - (2006). gamma agonists as regulators of microglial activation and brain inflammation. Curr. Pharm. Des. 12, 93-109. doi: 10.2174/138161206780574579

Boisvert, M., Cote, S., Vargas, A., Pasvanis, S., Bounou, S., Barbeau, B., et al. (2008). PGJ2 antagonizes NF-kappaB-induced HIV-1 LTR activation in colonic epithelial cells. Virology 380, 1-11. doi: 10.1016/j.virol.2008.07.023

Brightling, C. E., Brusselle, G., and Altman, P. (2020). The impact of the prostaglandin D2 receptor 2 and its downstream effects on the pathophysiology of asthma. Allergy 75, 761-768. doi: 10.1111/all.14001

Brys, M., Morel, A., Forma, E., Krzeslak, A., Wilkosz, J., Rozanski, W., et al. (2013). Relationship of urinary isoprostanes to prostate cancer occurrence. Mol. Cell Biochem. 372, 149-153. doi: 10.1007/s11010-012-1455-z

Buckner, M. M., Antunes, L. C., Gill, N., Russell, S. L., Shames, S. R., and Finlay, B. B. (2013). 15-Deoxy-Delta12,14-prostaglandin J2 inhibits macrophage colonization by Salmonella enterica serovar Typhimurium. PLoS One 8:e69759. doi: 10.1371/journal.pone.0069759

Burstein, S. H. (2020). The chemistry, biology and pharmacology of the cyclopentenone prostaglandins. Prostaglandins. Lipid. Mediat. 148:106408. doi: 10.1016/j.prostaglandins.2020.106408

Bussolati, B., and Mason, J. C. (2006). Dual role of VEGF-induced hemeoxygenase-1 in angiogenesis. Antioxid. Redox Signal. 8, 1153-1163. doi: 10. 1089/ars.2006.8.1153

Caldas, L. A., Ferreira, D. F., and Freitas, T. R. P. (2018). Prostaglandin A1 triggers Mayaro virus inhibition and heat shock protein 70 expression in an epithelial cell model. Rev. Soc. Bras. Med. Trop. 51, 584-590. doi: 10.1590/0037-86820235-2018

Carta, S., La Frazia, S., Donatelli, I., Puzelli, S., Rossi, A., and Santoro, M. G. (2014). Prostaglandin A1 inhibits avian influenza virus replication at a postentry level: Effect on virus protein synthesis and NF-kappaB activity. Prostaglandins Leukot. Essent Fatty Acids. 91, 311-323. doi: 10.1016/j.plefa.2014.07.009 
Castrillo, A., Diaz-Guerra, M. J., Hortelano, S., Martin-Sanz, P., and Bosca, L. (2000). Inhibition of IkappaB kinase and IkappaB phosphorylation by 15deoxy-Delta(12,14)-prostaglandin J(2) in activated murine macrophages. Mol. Cell Biol. 20, 1692-1698. doi: 10.1128/mcb.20.5.1692-1698.2000

Cernuda-Morollon, E., Pineda-Molina, E., Canada, F. J., and Perez-Sala, D. (2001). 15-Deoxy-Delta 12,14-prostaglandin J2 inhibition of NF-kappaB-DNA binding through covalent modification of the p50 subunit. J. Biol. Chem. 276, 3553035536. doi: 10.1074/jbc.m104518200

Chearwae, W., and Bright, J. J. (2008). PPARgamma agonists inhibit growth and expansion of CD133+ brain tumour stem cells. Br. J. Cancer 99, 2044-2053. doi: 10.1038/sj.bjc.6604786

Chen, S., Liu, C., Wang, X., Li, X., Chen, Y., and Tang, N. (2014). 15-DeoxyDelta(12,14)-prostaglandin J2 (15d-PGJ2) promotes apoptosis of HBx-positive liver cells. Chem. Biol. Interact. 214, 26-32. doi: 10.1016/j.cbi.2014.02.009

Chima, R. S., LaMontagne, T., Piraino, G., Hake, P. W., Denenberg, A., and Zingarelli, B. (2011). C-peptide, a novel inhibitor of lung inflammation following hemorrhagic shock. Am. J. Physiol. Lung Cell. Mole. Physiol. 300, L730-L739.

Chinery, R., Coffey, R. J., Graves-Deal, R., Kirkland, S. C., Sanchez, S. C., Zackert, W. E., et al. (1999). Prostaglandin J2 and 15-deoxy-delta12,14-prostaglandin J2 induce proliferation of cyclooxygenase-depleted colorectal cancer cells. Cancer Res. 59, 2739-2746.

Ciabattoni, G., Davi, G., Collura, M., Iapichino, L., Pardo, F., Ganci, A., et al. (2000). In vivo lipid peroxidation and platelet activation in cystic fibrosis. Am. J. Respir. Crit. Care Med. 162(4 Pt 1), 1195-1201.

Cloutier, A., Marois, I., Cloutier, D., Verreault, C., Cantin, A. M., and Richter, M. V. (2012). The prostanoid 15-deoxy-Delta12,14-prostaglandin-j2 reduces lung inflammation and protects mice against lethal influenza infection. J. Infect. Dis. 205, 621-630. doi: 10.1093/infdis/jir804

Cocca, C., Dorado, J., Calvo, E., Lopez, J. A., Santos, A., and Perez-Castillo, A. (2009). 15-Deoxi-Delta(12,14)-prostaglandin J2 is a tubulin-binding agent that destabilizes microtubules and induces mitotic arrest. Biochem. Pharmacol. 78, 1330-1339. doi: 10.1016/j.bcp.2009.06.100

Collins, C. E., Quaggiotto, P., Wood, L., O’Loughlin, E. V., Henry, R. L., and Garg, M. L. (1999). Elevated plasma levels of F2 alpha isoprostane in cystic fibrosis. Lipids 34, 551-556. doi: 10.1007/s11745-999-0397-1

Conti, C., Mastromarino, P., Tomao, P., De Marco, A., Pica, F., and Santoro, M. G. (1996). Inhibition of poliovirus replication by prostaglandins A and J in human cells. Antimicrob. Agents Chemother. 40, 367-372. doi: 10.1128/aac.40.2.367

Conti, G., Portincasa, P., Visalli, S., and Chezzi, C. (2001). Inhibition by prostaglandin $\mathrm{PGA}_{1}$ on the multiplication of influenza virus is a dosedependent effect. Virus Res. 75, 43-57. doi: 10.1016/s0168-1702(01)002210

Conti, M. (2006). Cyclopentenone: a special moiety for anticancer drug design. Anticancer Drugs 17, 1017-1022. doi: 10.1097/01.cad.0000231471.54288.00

Coutinho, D. S., Anjos-Valotta, E. A., do Nascimento, C., Pires, A. L. A., Napimoga, M. H., Carvalho, V. F., et al. (2017). 15-Deoxy-Delta-12,14-Prostaglandin J2 Inhibits Lung Inflammation and Remodeling in Distinct Murine Models of Asthma. Front. Immunol. 8:740.

D’Amico, E., Factor-Litvak, P., Santella, R. M., and Mitsumoto, H. (2013). Clinical perspective on oxidative stress in sporadic amyotrophic lateral sclerosis. Free Radic. Biol. Med. 65, 509-527. doi: 10.1016/j.freeradbiomed.2013.06.029

De Felice, C., Ciccoli, L., Leoncini, S., Signorini, C., Rossi, M., Vannuccini, L., et al. (2009). Systemic oxidative stress in classic Rett syndrome. Free Radic. Biol. Med. 47, 440-448. doi: 10.1016/j.freeradbiomed.2009.05.016

De Felice, C., Signorini, C., Durand, T., Oger, C., Guy, A., Bultel-Ponce, V., et al. (2011). F2-dihomo-isoprostanes as potential early biomarkers of lipid oxidative damage in Rett syndrome. J. Lipid. Res. 52, 2287-2297. doi: 10.1194/jlr.p017798

de Melo, N. F., de Macedo, C. G., Bonfante, R., Abdalla, H. B., da Silva, C. M., Pasquoto, T., et al. (2016). 15d-PGJ2-Loaded Solid Lipid Nanoparticles: Physicochemical Characterization and Evaluation of Pharmacological Effects on Inflammation. PLoS One 11:e0161796. doi: 10.1371/journal.pone.0161796

de Oliveira, D. N., Lima, E. O., Melo, C., Delafiori, J., Guerreiro, T. M., Rodrigues, R. G. M., et al. (2019). Inflammation markers in the saliva of infants born from Zika-infected mothers: exploring potential mechanisms of microcephaly during fetal development. Sci. Rep. 9:13606.

Diers, A. R., Higdon, A. N., Ricart, K. C., Johnson, M. S., Agarwal, A., Kalyanaraman, B., et al. (2010). Mitochondrial targeting of the electrophilic lipid 15-deoxy-Delta12,14-prostaglandin J2 increases apoptotic efficacy via redox cell signalling mechanisms. Biochem. J. 426, 31-41. doi: 10.1042/ bj20091293

Dionne, S., Levy, E., Levesque, D., and Seidman, E. G. (2010). PPARgamma ligand 15-deoxy-delta 12,14-prostaglandin J2 sensitizes human colon carcinoma cells to TWEAK-induced apoptosis. Anticancer Res. 30, 157-166.

D’Onofrio, C., Amici, C., Puglianiello, A., Faraoni, I., Lanzilli, G., Santoro, M. G., et al. (1992). Comparative anti-viral and anti-proliferative activity of PGA and PGJ2 against HTLV-I-infected MT-2 cells. Int. J. Cancer. 51, 481-488. doi: 10.1002/ijc.2910510324

Durand, T., De Felice, C., Signorini, C., Oger, C., Bultel-Ponce, V., Guy, A., et al. (2013). F(2)-Dihomo-isoprostanes and brain white matter damage in stage 1 Rett syndrome. Biochimie 95, 86-90. doi: 10.1016/j.biochi.2012.09.017

Fessel, J. P., Hulette, C., Powell, S., Roberts, L. J. II, and Zhang, J. (2003). Isofurans, but not F2-isoprostanes, are increased in the substantia nigra of patients with Parkinson's disease and with dementia with Lewy body disease. J. Neurochem. 85, 645-650. doi: 10.1046/j.1471-4159.2003.01709.x

Figarella, K., Uzcategui, N. L., Beck, A., Schoenfeld, C., Kubata, B. K., Lang, F., et al. (2006). Prostaglandin-induced programmed cell death in Trypanosoma brucei involves oxidative stress. Cell Death Differ. 13, 1802-1814. doi: 10.1038/sj.cdd. 4401862

Figueiredo-Pereira, M. E., Rockwell, P., Schmidt-Glenewinkel, T., and Serrano, P. (2014). Neuroinflammation and J2 prostaglandins: linking impairment of the ubiquitin-proteasome pathway and mitochondria to neurodegeneration. Front. Mol. Neurosci. 7:104.

Flores, J. J., Klebe, D., Rolland, W. B., Lekic, T., Krafft, P. R., and Zhang, J. H. (2016). PPARgamma-induced upregulation of CD36 enhances hematoma resolution and attenuates long-term neurological deficits after germinal matrix hemorrhage in neonatal rats. Neurobiol. Dis. 87, 124-133. doi: 10.1016/j.nbd. 2015.12.015

Forman, B. M., Chen, J., and Evans, R. M. (1996). The peroxisome proliferatoractivated receptors: ligands and activators. Ann. N. Y. Acad. Sci. 804, 266-275. doi: 10.1111/j.1749-6632.1996.tb18621.x

Forman, B. M., Tontonoz, P., Chen, J., Brun, R. P., Spiegelman, B. M., and Evans, R. M. (1995). 15-Deoxy-delta 12, 14-prostaglandin J2 is a ligand for the adipocyte determination factor PPAR gamma. Cell 83, 803-812. doi: 10.1016/ 0092-8674(95)90193-0

Fu, Y. G., Sung, J. J., Wu, K. C., Bai, A. H., Chan, M. C., Yu, J., et al. (2006). Inhibition of gastric cancer cells associated angiogenesis by $15 \mathrm{~d}$-prostaglandin J2 through the downregulation of angiopoietin-1. Cancer Lett. 243, 246-254. doi: 10.1016/j.canlet.2005.11.039

Funovics, P., Brostjan, C., Nigisch, A., Fila, A., Grochot, A., Mleczko, K., et al. (2006). Effects of 15d-PGJ(2) on VEGF-induced angiogenic activities and expression of VEGF receptors in endothelial cells. Prostaglandins Lipid. Mediat. 79, 230-244. doi: 10.1016/j.prostaglandins.2006.02.002

Garzon, B., Oeste, C. L., Diez-Dacal, B., and Perez-Sala, D. (2011). Proteomic studies on protein modification by cyclopentenone prostaglandins: expanding our view on electrophile actions. J. Proteomics. 74, 2243-2263. doi: 10.1016/j. jprot.2011.03.028

Giannelli, G., Villa, E., and Lahn, M. (2014). Transforming growth factor-beta as a therapeutic target in hepatocellular carcinoma. Cancer Res. 74, 1890-1894. doi: 10.1158/0008-5472.can-14-0243

Giri, S., Rattan, R., Singh, A. K., and Singh, I. (2004). The 15-deoxy-delta12,14prostaglandin $\mathrm{J} 2$ inhibits the inflammatory response in primary rat astrocytes via down-regulating multiple steps in phosphatidylinositol 3-kinase-AktNF-kappaB-p300 pathway independent of peroxisome proliferator-activated receptor gamma. J. Immunol. 173, 5196-5208. doi: 10.4049/jimmunol.173.8. 5196

Gorrindo, P., Lane, C. J., Lee, E. B., McLaughlin, B., and Levitt, P. (2013). Enrichment of elevated plasma F2t-isoprostane levels in individuals with autism who are stratified by presence of gastrointestinal dysfunction. PLoS One 8:e68444. doi: 10.1371/journal.pone.0068444

Griffin, D. E., Wesselingh, S. L., and McArthur, J. C. (1994). Elevated central nervous system prostaglandins in human immunodeficiency virus-associated dementia. Ann. Neurol. 35, 592-597. doi: 10.1002/ana.410350513

Guo, H., Callaway, J. B., and Ting, J. P. (2015). Inflammasomes: mechanism of action, role in disease, and therapeutics. Nat. Med. 21, 677-687. doi: 10.1038/ nm.3893 
Hamberg, M., and Samuelsson, B. (1966). Prostaglandins in human seminal plasma. Prostaglandins and related factors 46. J. Biol. Chem. 241, 257-263.

Han, H., Shin, S. W., Seo, C. Y., Kwon, H. C., Han, J. Y., Kim, I. H., et al. (2007). 15-Deoxy-delta 12,14-prostaglandin J2 (15d-PGJ 2) sensitizes human leukemic HL-60 cells to tumor necrosis factor-related apoptosis-inducing ligand (TRAIL)-induced apoptosis through Akt downregulation. Apoptosis 12, 2101-2114. doi: 10.1007/s10495-007-0124-2

Hanna, V. S., and Hafez, E. A. A. (2018). Synopsis of arachidonic acid metabolism: A review. J. Adv. Res. 11, 23-32. doi: 10.1016/j.jare.2018.03.005

Haslmayer, P., Thalhammer, T., Jager, W., Aust, S., Steiner, G., Ensinger, C., et al. (2002). The peroxisome proliferator-activated receptor gamma ligand 15deoxy-Delta12,14-prostaglandin J2 induces vascular endothelial growth factor in the hormone-independent prostate cancer cell line PC 3 and the urinary bladder carcinoma cell line 5637. Int. J. Oncol. 21, 915-920.

Hernandez, J. M., Floyd, D. H., Weilbaecher, K. N., Green, P. L., and Boris-Lawrie, K. (2008). Multiple facets of junD gene expression are atypical among AP-1 family members. Oncogene 27, 4757-4767. doi: 10.1038/onc.2008.120

Hirata, Y., Hayashi, H., Ito, S., Kikawa, Y., Ishibashi, M., Sudo, M., et al. (1988). Occurrence of 9-deoxy-delta 9,delta 12-13,14-dihydroprostaglandin D2 in human urine. J. Biol. Chem. 263, 16619-16625. doi: 10.1016/s0021-9258(18) 37435-0

Hornsleth, A., Loland, L., and Larsen, L. B. (2001). Cytokines and chemokines in respiratory secretion and severity of disease in infants with respiratory syncytial virus (RSV) infection. J. Clin. Virol. 21, 163-170. doi: 10.1016/s1386-6532(01) 00159-7

Hsu, H. T., and Chi, C. W. (2014). Emerging role of the peroxisome proliferatoractivated receptor-gamma in hepatocellular carcinoma. J. Hepatocell Carcinoma. 1, 127-135. doi: 10.2147/jhc.s48512

Huan, T., Tran, T., Zheng, J., Sapkota, S., MacDonald, S. W., Camicioli, R., et al. (2018). Metabolomics Analyses of Saliva Detect Novel Biomarkers of Alzheimer's Disease. J. Alzheimers Dis. 65, 1401-1416. doi: 10.3233/jad-180711

Hughes-Fulford, M., McGrath, M. S., Hanks, D., Erickson, S., and Pulliam, L. (1992). Effects of dimethyl prostaglandin A1 on herpes simplex virus and human immunodeficiency virus replication. Antimicrob. Agents Chemother. 36, 2253-2258. doi: 10.1128/aac.36.10.2253

Inoue, H., Tanabe, T., and Umesono, K. (2000). Feedback control of cyclooxygenase-2 expression through PPARgamma. J. Biol. Chem. 275, 2802828032. doi: $10.1074 / \mathrm{jbc}$. 001387200

Inoue, M., Itoh, H., Tanaka, T., Chun, T. H., Doi, K., Fukunaga, Y., et al. (2001). Oxidized LDL regulates vascular endothelial growth factor expression in human macrophages and endothelial cells through activation of peroxisome proliferator-activated receptor-gamma. Arterioscler. Thromb. Vasc. Biol. 21, 560-566. doi: 10.1161/01.atv.21.4.560

Itoh, K., Mochizuki, M., Ishii, Y., Ishii, T., Shibata, T., Kawamoto, Y., et al. (2004). Transcription factor Nrf2 regulates inflammation by mediating the effect of 15deoxy-Delta(12,14)-prostaglandin j(2). Mol. Cell Biol. 24, 36-45. doi: 10.1128/ mcb.24.1.36-45.2004

Janabi, N. (2002). Selective inhibition of cyclooxygenase-2 expression by 15-deoxyDelta $(12,14)(12,14)$-prostaglandin J(2) in activated human astrocytes, but not in human brain macrophages. J. Immunol. 168, 4747-4755. doi: 10.4049/ jimmunol.168.9.4747

Jandl, K., and Heinemann, A. (2017). The therapeutic potential of CRTH2/DP2 beyond allergy and asthma. Prostaglandins Lipid. Mediat. 133, 42-48. doi: 10.1016/j.prostaglandins.2017.08.006

Jang, H. Y., Hong, O. Y., Youn, H. J., Kim, M. G., Kim, C. H., Jung, S. H., et al. (2020). 15d-PGJ2 inhibits NF-kappaB and AP-1-mediated MMP-9 expression and invasion of breast cancer cell by means of a heme oxygenase-1-dependent mechanism. BMB Rep. 53, 212-217. doi: 10.5483/bmbrep.2020.53.4.164

Ji, J. D., Kim, H. J., Rho, Y. H., Choi, S. J., Lee, Y. H., Cheon, H. J., et al. (2005). Inhibition of IL-10-induced STAT3 activation by 15-deoxy-Delta12,14prostaglandin J2. Rheumatology 44, 983-988. doi: 10.1093/rheumatology/ keh657

Jozkowicz, A., Huk, I., Nigisch, A., Weigel, G., Weidinger, F., and Dulak, J. (2002). Effect of prostaglandin-J(2) on VEGF synthesis depends on the induction of heme oxygenase-1. Antioxid Redox Signal. 4, 577-585. doi: 10.1089/ 15230860260220076

Jozkowicz, A., Nigisch, A., Wegrzyn, J., Weigel, G., Huk, I., and Dulak, J. (2004). Opposite effects of prostaglandin-J2 on VEGF in normoxia and hypoxia: role of
HIF-1. Biochem. Biophys. Res. Commun. 314, 31-38. doi: 10.1016/j.bbrc.2003. 12.059

Kalantari, P., Narayan, V., Henderson, A. J., and Prabhu, K. S. (2009). 15Deoxy-Delta12,14-prostaglandin J2 inhibits HIV-1 transactivating protein, Tat, through covalent modification. FASEB J. 23, 2366-2373. doi: 10.1096/fj.08124982

Kansanen, E., Kivela, A. M., and Levonen, A. L. (2009). Regulation of Nrf2-dependent gene expression by 15-deoxy-Delta12,14-prostaglandin J2. Free Radic. Biol. Med. 47, 1310-1317. doi: 10.1016/j.freeradbiomed.2009. 06.030

Kaplan, J. M., Cook, J. A., Hake, P. W., O'Connor, M., Burroughs, T. J., and Zingarelli, B. (2005). 15-Deoxy-delta(12,14)-prostaglandin J(2) (15D-PGJ(2)), a peroxisome proliferator activated receptor gamma ligand, reduces tissue leukosequestration and mortality in endotoxic shock. Shock 24, 59-65. doi: 10.1097/01.shk.0000167108.88376.f2

Kaplan, J. M., Denenberg, A., Monaco, M., Nowell, M., Wong, H., and Zingarelli, B. (2010). Changes in peroxisome proliferator-activated receptor-gamma activity in children with septic shock. Intens. Care Med. 36, 123-130. doi: 10.1007/ s00134-009-1654-6

Kapoor, M., Kojima, F., Qian, M., Yang, L., and Crofford, L. J. (2007). Microsomal prostaglandin E synthase-1 deficiency is associated with elevated peroxisome proliferator-activated receptor gamma: regulation by prostaglandin E2 via the phosphatidylinositol 3-kinase and Akt pathway. J. Biol. Chem. 282, 5356-5366. doi: $10.1074 / \mathrm{jbc}$.m610153200

Kapoor, R., and Huang, Y. S. (2006). Gamma linolenic acid: an antiinflammatory omega-6 fatty acid. Curr. Pharm. Biotechnol. 7, 531-534. doi: 10.2174/ 138920106779116874

Kato, T., Fukushima, M., Kurozumi, S., and Noyori, R. (1986). Antitumor activity of delta 7-prostaglandin A1 and delta 12-prostaglandin J2 in vitro and in vivo. Cancer Res. 46, 3538-3542.

Kim, E. H., Kim, D. H., Na, H. K., and Surh, Y. J. (2004). Effects of cyclopentenone prostaglandins on the expression of heme oxygenase-1 in MCF-7 cells. Ann. N. Y. Acad. Sci. 1030, 493-500. doi: 10.1196/annals.1329.061

Kim, E. H., Na, H. K., and Surh, Y. J. (2006). Upregulation of VEGF by 15-deoxyDelta12,14-prostaglandin J2 via heme oxygenase-1 and ERK1/2 signaling in MCF-7 cells. Ann. N. Y. Acad. Sci. 1090, 375-384. doi: 10.1196/annals.1378.041

Kim, H. J., Rho, Y. H., Choi, S. J., Lee, Y. H., Cheon, H., Um, J. W., et al. (2005). 15-Deoxy-delta12,14-PGJ2 inhibits IL-6-induced Stat3 phosphorylation in lymphocytes. Exp. Mol. Med. 37, 179-185. doi: 10.1038/emm.2005.24

Kim, I. K., Lee, J. H., Sohn, H. W., Kim, H. S., and Kim, S. H. (1993). Prostaglandin $\mathrm{A} 2$ and delta 12-prostaglandin J2 induce apoptosis in L1210 cells. FEBS Lett. 321, 209-214. doi: 10.1016/0014-5793(93)80110-g

Kim, K. R., Kim, H. J., Lee, S. K., Ma, G. T., Park, K. K., and Chung, W. Y. (2015). 15-deoxy-delta12,14-prostaglandin j2 inhibits osteolytic breast cancer bone metastasis and estrogen deficiency-induced bone loss. PLoS One 10:e0122764. doi: 10.1371/journal.pone.0122764

Kim, Y., Ratziu, V., Choi, S. G., Lalazar, A., Theiss, G., Dang, Q., et al. (1998). Transcriptional activation of transforming growth factor betal and its receptors by the Kruppel-like factor Zf9/core promoter-binding protein and Sp1. Potential mechanisms for autocrine fibrogenesis in response to injury. J. Biol. Chem. 273, 33750-33758. doi: 10.1074/jbc.273.50.33750

Kitz, K., Windischhofer, W., Leis, H. J., Huber, E., Kollroser, M., and Malle, E. (2011). 15-Deoxy-Delta12,14-prostaglandin J2 induces Cox-2 expression in human osteosarcoma cells through MAPK and EGFR activation involving reactive oxygen species. Free Radic Biol. Med. 50, 854-865. doi: 10.1016/j. freeradbiomed.2010.12.039

Koharudin, L. M., Furey, W., and Gronenborn, A. M. (2011). Novel fold and carbohydrate specificity of the potent anti-HIV cyanobacterial lectin from Oscillatoria agardhii. J. Biol. Chem. 286, 1588-1597. doi: 10.1074/jbc.m110. 173278

Korade, Z., Xu, L., Mirnics, K., and Porter, N. A. (2013). Lipid biomarkers of oxidative stress in a genetic mouse model of Smith-Lemli-Opitz syndrome. J. Inherit. Metab. Dis. 36, 113-122. doi: 10.1007/s10545-012-9504-z

Kurakula, K., Koenis, D. S., van Tiel, C. M., and de Vries, C. J. (2014). NR4A nuclear receptors are orphans but not lonesome. Biochim. Biophys. Acta 1843, 2543-2555. doi: 10.1016/j.bbamcr.2014.06.010

Kweider, N., Fragoulis, A., Rosen, C., Pecks, U., Rath, W., Pufe, T., et al. (2011). Interplay between vascular endothelial growth factor (VEGF) and nuclear factor 
erythroid 2-related factor-2 (Nrf2): implications for preeclampsia. J. Biol. Chem. 286, 42863-42872. doi: 10.1074/jbc.m111.286880

Lacal, P. M., Amici, C., Bonmassar, E., and D’Onofrio, C. (1994a). Effects of cyclopentenone prostaglandins on myeloid cells during early infection with HTLV-I. II. Regulation of synthesis of inducible p72 heat shock protein. J. Pharmacol. Exp. Ther. 271, 1096-1102.

Lacal, P. M., Puglianiello, A., Bonmassar, E., and D’Onofrio, C. (1994b). Effects of cyclopentenone prostaglandins on myeloid cells during early infection with HTLV-I. I. Cell differentiation determines sensitivity to prostaglandins and virus infection. J. Pharmacol. Exp. Ther. 271, 1086-1095.

Lawrence, T. (2009). The nuclear factor NF-kappaB pathway in inflammation. Cold Spr. Harb. Perspect. Biol. 1:a001651.

Lee, H. J., Su, Y., Yin, P. H., Lee, H. C., and Chi, C. W. (2009). PPAR(gamma)/PGC1(alpha) pathway in E-cadherin expression and motility of HepG2 cells. Anticancer Res. 29, 5057-5063.

Lee, S. E., and Park, Y. S. (2013). Role of lipid peroxidation-derived alpha, beta-unsaturated aldehydes in vascular dysfunction. Oxid. Med. Cell Longev. 2013:629028.

Lee, S. J., Yang, E. K., and Kim, S. G. (2006). Peroxisome proliferator-activated receptor-gamma and retinoic acid $\mathrm{X}$ receptor alpha represses the TGFbetal gene via PTEN-mediated p70 ribosomal S6 kinase-1 inhibition: role for Zf9 dephosphorylation. Mol. Pharmacol. 70, 415-425. doi: 10.1124/mol.106.022954

Levonen, A. L., Dickinson, D. A., Moellering, D. R., Mulcahy, R. T., Forman, H. J., and Darley-Usmar, V. M. (2001). Biphasic effects of 15-deoxydelta(12,14)-prostaglandin $\mathrm{J}(2)$ on glutathione induction and apoptosis in human endothelial cells. Arterioscler. Thromb. Vasc. Biol. 21, 1846-1851. doi: 10.1161/hq1101.098488

Levonen, A. L., Landar, A., Ramachandran, A., Ceaser, E. K., Dickinson, D. A., Zanoni, G., et al. (2004). Cellular mechanisms of redox cell signalling: role of cysteine modification in controlling antioxidant defences in response to electrophilic lipid oxidation products. Biochem. J. 378(Pt 2), 373-382. doi: $10.1042 / \mathrm{bj} 20031049$

Li, H., and Narahara, H. (2013). 15-Deoxy-Delta(12,14)-prostaglandin J(2) induces growth inhibition, cell cycle arrest and apoptosis in human endometrial cancer cell lines. Int. J. Mol. Med. 31, 778-788. doi: 10.3892/ijmm.2013.1268

Li, H., and Pauza, C. D. (2009). Effects of 15-deoxy-delta12,14-prostaglandin J2 (15d-PGJ2) and rosiglitazone on human gammadelta2 T cells. PLoS One 4:e7726. doi: 10.1371/journal.pone.0007726

Li, J., Guo, C., and Wu, J. (2019). 15-Deoxy-(12,14)-Prostaglandin J2 (15d-PGJ2), an Endogenous Ligand of PPAR-gamma: Function and Mechanism. PPAR Res. 2019:7242030.

Li, Y., Atkinson, K., and Zhang, T. (2017). Combination of chemotherapy and cancer stem cell targeting agents: Preclinical and clinical studies. Cancer Lett. 396, 103-109. doi: 10.1016/j.canlet.2017.03.008

Liang, X., Wu, L., Hand, T., and Andreasson, K. (2005). Prostaglandin D2 mediates neuronal protection via the DP1 receptor. J. Neurochem. 92, 477-486. doi: $10.1111 / j .1471-4159.2004 .02870 . x$

Lin, A., Minden, A., Martinetto, H., Claret, F. X., Lange-Carter, C., Mercurio, F., et al. (1995). Identification of a dual specificity kinase that activates the Jun kinases and p38-Mpk2. Science 268, 286-290. doi: 10.1126/science.7716521

Loboda, A., Damulewicz, M., Pyza, E., Jozkowicz, A., and Dulak, J. (2016). Role of Nrf2/HO-1 system in development, oxidative stress response and diseases: an evolutionarily conserved mechanism. Cell Mol. Life Sci. 73, 3221-3247. doi: 10.1007/s00018-016-2223-0

Magesh, S., Chen, Y., and Hu, L. (2012). Small molecule modulators of Keap1-Nrf2ARE pathway as potential preventive and therapeutic agents. Med. Res. Rev. 32, 687-726. doi: 10.1002/med.21257

Maier, N. K., Leppla, S. H., and Moayeri, M. (2015). The cyclopentenone prostaglandin 15d-PGJ2 inhibits the NLRP1 and NLRP3 inflammasomes. J. Immunol. 194, 2776-2785. doi: 10.4049/jimmunol.1401611

Mastromarino, P., Conti, C., Petruzziello, R., De Marco, A., Pica, F., and Santoro, M. G. (1993). Inhibition of Sindbis virus replication by cyclopentenone prostaglandins: a cell-mediated event associated with heat-shock protein synthesis. Antiviral. Res. 20, 209-222. doi: 10.1016/0166-3542(93)90021-a

Mc Guire, P. J., Parikh, A., and Diaz, G. A. (2009). Profiling of oxidative stress in patients with inborn errors of metabolism. Mol. Genet. Metab. 98, 173-180. doi: 10.1016/j.ymgme.2009.06.007
Milde-Langosch, K. (2005). The Fos family of transcription factors and their role in tumourigenesis. Eur. J. Cancer 41, 2449-2461. doi: 10.1016/j.ejca.2005.08.008

Millan, O., Rico, D., Peinado, H., Zarich, N., Stamatakis, K., Perez-Sala, D., et al. (2006). Potentiation of tumor formation by topical administration of 15-deoxydelta12,14-prostaglandin J2 in a model of skin carcinogenesis. Carcinogenesis 27, 328-336. doi: 10.1093/carcin/bgi213

Mills, E. L., Ryan, D. G., Prag, H. A., Dikovskaya, D., Menon, D., Zaslona, Z., et al. (2018). Itaconate is an anti-inflammatory metabolite that activates Nrf2 via alkylation of KEAP1. Nature 556, 113-117.

Minden, A., Lin, A., Claret, F. X., Abo, A., and Karin, M. (1995). Selective activation of the JNK signaling cascade and c-Jun transcriptional activity by the small GTPases Rac and Cdc42Hs. Cell 81, 1147-1157. doi: 10.1016/s0092-8674(05) 80019-4

Ming, X., Stein, T. P., Brimacombe, M., Johnson, W. G., Lambert, G. H., and Wagner, G. C. (2005). Increased excretion of a lipid peroxidation biomarker in autism. Prostaglandins Leukot. Essent Fatty Acids 73, 379-384. doi: 10.1016/ j.plefa.2005.06.002

Mochizuki, M., Ishii, Y., Itoh, K., Iizuka, T., Morishima, Y., Kimura, T., et al. (2005). Role of 15-deoxy delta $(12,14)$ prostaglandin $\mathrm{J} 2$ and Nrf2 pathways in protection against acute lung injury. Am. J. Respir. Crit. Care Med. 171, 1260-1266.

Monroy, M. A., Opperman, K. K., Pucciarelli, M., Yerrum, S., Berg, D. A., and Daly, J. M. T. H. E. (2007). PPARgamma ligand 15d-PGJ2 modulates macrophage activation after injury in a murine trauma model. Shock 28, 186-191. doi: 10.1097/shk.0b013e3180310982

Montine, T. J., Beal, M. F., Cudkowicz, M. E., O’Donnell, H., Margolin, R. A., McFarland, L., et al. (1999a). Increased CSF F2-isoprostane concentration in probable AD. Neurology 52, 562-565. doi: 10.1212/wnl.52.3.562

Montine, T. J., Beal, M. F., Robertson, D., Cudkowicz, M. E., Biaggioni, I., O'Donnell, H., et al. (1999b). Cerebrospinal fluid F2-isoprostanes are elevated in Huntington's disease. Neurology 52, 1104-1105. doi: 10.1212/wnl.52.5.1104

Montine, T. J., Markesbery, W. R., Morrow, J. D., and Roberts, L. J. II (1998). Cerebrospinal fluid F2-isoprostane levels are increased in Alzheimer's disease. Ann. Neurol. 44, 410-413. doi: 10.1002/ana.410440322

Montuschi, P., Barnes, P., and Roberts, L. J. II (2007). Insights into oxidative stress: the isoprostanes. Curr. Med. Chem. 14, 703-717. doi: 10.2174/ 092986707780059607

Montuschi, P., Kharitonov, S. A., Ciabattoni, G., Corradi, M., van Rensen, L., Geddes, D. M., et al. (2000). Exhaled 8-isoprostane as a new non-invasive biomarker of oxidative stress in cystic fibrosis. Thorax 55, 205-209. doi: 10. 1136/thorax.55.3.205

Morrow, J. D. (2005). Quantification of isoprostanes as indices of oxidant stress and the risk of atherosclerosis in humans. Arterioscler. Thromb. Vasc. Biol. 25, 279-286. doi: 10.1161/01.atv.0000152605.64964.c0

Mowen, K., and David, M. (2000). Regulation of STAT1 nuclear export by Jak1. Mol. Cell Biol. 20, 7273-7281. doi: 10.1128/mcb.20.19.7273-7281.2000

Mukherjee, R., Jow, L., Noonan, D., and McDonnell, D. P. (1994). Human and rat peroxisome proliferator activated receptors (PPARs) demonstrate similar tissue distribution but different responsiveness to PPAR activators. J. Steroid Biochem. Mol. Biol. 51, 157-166. doi: 10.1016/0960-0760(94)90089-2

Murillo, J. C., Dimov, V., and Gonzalez-Estrada, A. (2018). An evaluation of fevipiprant for the treatment of asthma: a promising new therapy? Exp. Opin. Pharmacother. 19, 2087-2093. doi: 10.1080/14656566.2018.154 0589

Musiek, E. S., Breeding, R. S., Milne, G. L., Zanoni, G., Morrow, J. D., and McLaughlin, B. (2006). Cyclopentenone isoprostanes are novel bioactive products of lipid oxidation which enhance neurodegeneration. J. Neurochem. 97, 1301-1313. doi: 10.1111/j.1471-4159.2006.03797.x

Musiek, E. S., McLaughlin, B., and Morrow, J. D. (2007). Electrophilic cyclopentenone isoprostanes in neurodegeneration. J. Mol. Neurosci. 33, 80-86. doi: 10.1007/s12031-007-0042-3

Nagata, N., Iwanari, H., Kumagai, H., Kusano-Arai, O., Ikeda, Y., Aritake, K., et al. (2017). Generation and characterization of an antagonistic monoclonal antibody against an extracellular domain of mouse DP2 (CRTH2/GPR44) receptors for prostaglandin D2. PLoS One 12:e0175452. doi: 10.1371/journal. pone. 0175452

Nakazawa, H., Chang, K., Shinozaki, S., Yasukawa, T., Ishimaru, K., Yasuhara, S., et al. (2017). iNOS as a Driver of Inflammation and Apoptosis in Mouse Skeletal 
Muscle after Burn Injury: Possible Involvement of Sirt1 S-NitrosylationMediated Acetylation of p65 NF-kappaB and p53. PLoS One 12:e0170391. doi: 10.1371/journal.pone. 0170391

Negishi, M., and Katoh, H. (2002). Cyclopentenone prostaglandin receptors. Prostaglandins. Lipid. Mediat. 6, 611-617. doi: 10.1016/s0090-6980(02)00059-x

Nikitakis, N. G., Siavash, H., Hebert, C., Reynolds, M. A., Hamburger, A. W., and Sauk, J. J. (2002). 15-PGJ2, but not thiazolidinediones, inhibits cell growth, induces apoptosis, and causes downregulation of Stat3 in human oral SCCa cells. Br. J. Cancer. 87, 1396-1403. doi: 10.1038/sj.bjc.6600618

Niro, S., Hennebert, O., and Morfin, R. A. (2010). native steroid hormone derivative triggers the resolution of inflammation. Horm Mol. Biol. Clin. Investig. 1, 11-19.

Nugteren, D. H., Van Dorp, D. A., Bergstrom, S., Hamberg, M., and Samuelsson, B. (1966). Absolute configuration of the prostaglandins. Nature 212, 38-39.

Oliva, J. L., Perez-Sala, D., Castrillo, A., Martinez, N., Canada, F. J., Bosca, L., et al. (2003). The cyclopentenone 15-deoxy-delta 12,14-prostaglandin J2 binds to and activates H-Ras. Proc. Natl. Acad. Sci. U S A. 100, 4772-4777. doi: 10.1073/pnas. 0735842100

Omeragic, A., Saikali, M. F., Currier, S., Volsky, D. J., Cummins, C. L., and Bendayan, R. (2020). Selective peroxisome proliferator-activated receptorgamma modulator, INT131 exhibits anti-inflammatory effects in an EcoHIV mouse model. FASEB J. 34, 1996-2010. doi: 10.1096/fj.201901874r

Pai, S., and Thomas, R. (2008). Immune deficiency or hyperactivity-Nf-kappab illuminates autoimmunity. J. Autoimmun. 31, 245-251. doi: 10.1016/j.jaut. 2008.04.012

Park, E. J., Park, S. Y., Joe, E. H., and Jou, I. (2003). 15d-PGJ2 and rosiglitazone suppress Janus kinase-STAT inflammatory signaling through induction of suppressor of cytokine signaling 1 (SOCS1) and SOCS3 in glia. J. Biol. Chem. 278, 14747-14752. doi: 10.1074/jbc.m210819200

Park, J. M., and Na, H. K. (2019a). 15-Deoxy-Delta(12,14)-prostaglandin J2 Upregulates the Expression of 15-Hydroxyprostaglandin Dehydrogenase by Inducing AP-1 Activation and Heme Oxygenase-1 Expression in Human Colon Cancer Cells. J. Cancer Prev. 24, 183-191. doi: 10.15430/jcp.2019.24.3.183

Park, J. M., and Na, H. K. (2019b). Erratum: 15-Deoxy-Delta(12,14)-prostaglandin J2 Upregulates the Expression of 15-Hydroxyprostaglandin Dehydrogenase by Inducing AP-1 Activation and Heme Oxygenase-1 Expression in Human Colon Cancer Cells. J. Cancer Prev. 24:245. doi: 10.15430/jcp.2019.24.4.245

Park, S. H., Kim, K. E., Hwang, H. Y., and Kim, T. Y. (2003). Regulatory effect of SOCS on NF-kappaB activity in murine monocytes/macrophages. DNA Cell Biol. 22, 131-139. doi: 10.1089/104454903321515931

Parker, J. (1995). Prostaglandin A2 protein interactions and inhibition of cellular proliferation. Prostaglandins 50, 359-375. doi: 10.1016/0090-6980(95)00136-0

Pearen, M. A., and Muscat, G. E. (2010). Minireview: Nuclear hormone receptor 4A signaling: implications for metabolic disease. Mol. Endocrinol. 24, 1891-1903. doi: 10.1210/me.2010-0015

Pearson, D., Weiss, H. M., Jin, Y., Jaap van Lier, J., Erpenbeck, V. J., Glaenzel, U., et al. (2017). Absorption, Distribution, Metabolism, and Excretion of the Oral Prostaglandin D2 Receptor 2 Antagonist Fevipiprant (QAW039) in Healthy Volunteers and In Vitro. Drug Metab. Dispos. 45, 817-825. doi: 10.1124/dmd. 117.075358

Peeraully, M. R., Sievert, H., Bullo, M., Wang, B., and Trayhurn, P. (2006). Prostaglandin D2 and J2-series (PGJ2, Delta12-PGJ2) prostaglandins stimulate IL-6 and MCP-1, but inhibit leptin, expression and secretion by 3T3L1 adipocytes. Pflugers Arch. 453, 177-187. doi: 10.1007/s00424-006$0118-\mathrm{x}$

Perez-Sala, D., Cernuda-Morollon, E., and Canada, F. J. (2003). Molecular basis for the direct inhibition of AP-1 DNA binding by 15-deoxy-Delta 12,14-prostaglandin J2. J. Biol. Chem. 278, 51251-51260. doi: 10.1074/jbc. m309409200

Phulwani, N. K., Feinstein, D. L., Gavrilyuk, V., Akar, C., and Kielian, T. (2006). 15-deoxy-Delta12,14-prostaglandin J2 (15d-PGJ2) and ciglitazone modulate Staphylococcus aureus-dependent astrocyte activation primarily through a PPAR-gamma-independent pathway. J. Neurochem. 99, 1389-1402. doi: 10. 1111/j.1471-4159.2006.04183.x

Pica, F., De Marco, A., De Cesare, F., and Santoro, M. G. (1993). Inhibition of vesicular stomatitis virus replication by delta 12 -prostaglandin $\mathrm{J} 2$ is regulated at two separate levels and is associated with induction of stress protein synthesis. Antiviral. Res. 20, 193-208. doi: 10.1016/0166-3542(93)90020-j
Pica, F., Palamara, A. T., Rossi, A., De Marco, A., Amici, C., and Santoro, M. G. (2000). Delta(12)-prostaglandin J(2) is a potent inhibitor of influenza A virus replication. Antimicrob. Agents Chemother. 44, 200-204. doi: 10.1128/aac.44.1. 200-204.2000

Porta, A., Pasi, M., Brunoldi, E., Zanoni, G., and Vidari, G. (2013). Biology and chemistry of neuroprostanes. First total synthesis of 17-A4-NeuroP: validation of a convergent strategy to a number of cyclopentenone neuroprostanes. Chem. Phys. Lipids. 174, 64-74. doi: 10.1016/j.chemphyslip.2013.07.002

Pratico, D., Clark, C. M., Lee, V. M., Trojanowski, J. Q., Rokach, J., and FitzGerald, G. A. (2000). Increased 8,12-iso-iPF2alpha-VI in Alzheimer's disease: correlation of a noninvasive index of lipid peroxidation with disease severity. Ann. Neurol. 48, 809-812. doi: 10.1002/1531-8249(200011)48:5<809:: aid-ana19>3.0.co;2-9

Pratico, D., Myl, V., Trojanowski, J. Q., Rokach, J., and Fitzgerald, G. A. (1998). Increased F2-isoprostanes in Alzheimer's disease: evidence for enhanced lipid peroxidation in vivo. FASEB J. 12, 1777-1783. doi: 10.1096/fasebj.12.15.1777

Rajakariar, R., Hilliard, M., Lawrence, T., Trivedi, S., Colville-Nash, P., Bellingan, G., et al. (2007). Hematopoietic prostaglandin D2 synthase controls the onset and resolution of acute inflammation through PGD2 and 15-deoxyDelta12 14 PGJ2. Proc. Natl. Acad. Sci. U S A. 104, 20979-20984. doi: 10.1073/pnas. 0707394104

Rajan, S., Jang, Y., Kim, C. H., Kim, W., Toh, H. T., Jeon, J., et al. (2020). PGE1 and $\mathrm{PGA}_{1}$ bind to Nurr1 and activate its transcriptional function. Nat. Chem. Biol. 16, 876-886. doi: 10.1038/s41589-020-0553-6

Ricote, M., Huang, J., Fajas, L., Li, A., Welch, J., Najib, J., et al. (1998a). Expression of the peroxisome proliferator-activated receptor gamma (PPARgamma) in human atherosclerosis and regulation in macrophages by colony stimulating factors and oxidized low density lipoprotein. Proc. Natl. Acad. Sci. U S A. 95, 7614-7619. doi: 10.1073/pnas.95.13.7614

Ricote, M., Li, A. C., Willson, T. M., Kelly, C. J., and Glass, C. K. (1998b). The peroxisome proliferator-activated receptor-gamma is a negative regulator of macrophage activation. Nature 391, 79-82. doi: 10.1038/34178

Rosenberger, T. A., Villacreses, N. E., Hovda, J. T., Bosetti, F., Weerasinghe, G., Wine, R. N., et al. (2004). Rat brain arachidonic acid metabolism is increased by a 6-day intracerebral ventricular infusion of bacterial lipopolysaccharide. J. Neurochem. 88, 1168-1178. doi: 10.1046/j.1471-4159.2003.02246.x

Rossi, A., Elia, G., and Santoro, M. G. (1997). Inhibition of nuclear factor kappa B by prostaglandin A1: an effect associated with heat shock transcription factor activation. Proc. Natl. Acad. Sci. U S A. 94, 746-750. doi: 10.1073/pnas.94.2.746

Rossi, A., Kapahi, P., Natoli, G., Takahashi, T., Chen, Y., Karin, M., et al. (2000). Anti-inflammatory cyclopentenone prostaglandins are direct inhibitors of IkappaB kinase. Nature 403, 103-108. doi: 10.1038/47520

Rossi, P., Riutta, A., Kuukasjarvi, P., Vehmas, T., Mucha, I., and Salenius, J. P. (2004). Revascularization decreases 8-isoprostaglandin F2alpha excretion in chronic lower limb ischemia. Prostaglandins Leukot. Essent Fatty Acids 71, 97-101. doi: 10.1016/j.plefa.2004.01.003

Rossner, P. Jr., Gammon, M. D., Terry, M. B., Agrawal, M., Zhang, F. F., Teitelbaum, S. L., et al. (2006). Relationship between urinary 15-F2t-isoprostane and 8-oxodeoxyguanosine levels and breast cancer risk. Cancer Epidemiol. Biomarkers Prev. 15, 639-644. doi: 10.1158/1055-9965.epi-05-0554

Rozera, C., Carattoli, A., De Marco, A., Amici, C., Giorgi, C., and Santoro, M. G. (1996). Inhibition of HIV-1 replication by cyclopentenone prostaglandins in acutely infected human cells. Evidence for a transcriptional block. J. Clin. Invest. 97, 1795-1803. doi: 10.1172/jci118609

Saarialho-Kere, U. K., Chang, E. S., Welgus, H. G., and Parks, W. C. (1993). Expression of interstitial collagenase, $92-\mathrm{kDa}$ gelatinase, and tissue inhibitor of metalloproteinases-1 in granuloma annulare and necrobiosis lipoidica diabeticorum. J. Invest. Dermatol. 100, 335-342. doi: 10.1111/1523-1747. ep12470032

Sakamoto, H., Corcoran, T. B., Laffey, J. G., and Shorten, G. D. (2002). Isoprostanes-markers of ischaemia reperfusion injury. Eur. J. Anaesthesiol. 19, 550-559. doi: 10.1017/s0265021502000893

Sandham, D. A., Barker, L., Brown, L., Brown, Z., Budd, D., Charlton, S. J., et al. (2017a). Correction to "Discovery of Fevipiprant (NVP-QAW039), a Potent and Selective DP2 Receptor Antagonist for Treatment of Asthma". ACS Med. Chem. Lett. 8:987. doi: 10.1021/acsmedchemlett.7b00353

Sandham, D. A., Barker, L., Brown, L., Brown, Z., Budd, D., Charlton, S. J., et al. (2017b). Discovery of Fevipiprant (NVP-QAW039), a Potent and Selective 
DP2 Receptor Antagonist for Treatment of Asthma. ACS Med. Chem. Lett. 8, 582-586. doi: 10.1021/acsmedchemlett.7b00157

Santoro, M. G., Fukushima, M., Benedetto, A., and Amici, C. (1987). PGJ2, a new antiviral prostaglandin: inhibition of Sendai virus replication and alteration of virus protein synthesis. J. Gen. Virol. 68(Pt 4), 1153-1158. doi: 10.1099/00221317-68-4-1153

Sato, H., Ishihara, S., Kawashima, K., Moriyama, N., Suetsugu, H., Kazumori, H., et al. (2000). Expression of peroxisome proliferator-activated receptor (PPAR)gamma in gastric cancer and inhibitory effects of PPARgamma agonists. Br. J. Cancer 83, 1394-1400. doi: 10.1054/bjoc.2000.1457

Sayre, L. M., Lin, D., Yuan, Q., Zhu, X., and Tang, X. (2006). Protein adducts generated from products of lipid oxidation: focus on HNE and one. Drug. Metab. Rev. 38, 651-675. doi: 10.1080/03602530600959508

Scher, J. U., and Pillinger, M. H. (2005). 15d-PGJ2: the anti-inflammatory prostaglandin? Clin. Immunol. 114, 100-109. doi: 10.1016/j.clim.2004.09.008

Seet, R. C., Lee, C. Y., Lim, E. C., Tan, J. J., Quek, A. M., Chong, W. L., et al. (2010). Oxidative damage in Parkinson disease: Measurement using accurate biomarkers. Free Radic. Biol. Med. 48, 560-566. doi: 10.1016/j.freeradbiomed. 2009.11.026

Seif, F., Khoshmirsafa, M., Aazami, H., Mohsenzadegan, M., Sedighi, G., and Bahar, M. (2017). The role of JAK-STAT signaling pathway and its regulators in the fate of T helper cells. Cell Commun. Signal. 15, 23.

Senftleben, U., Cao, Y., Xiao, G., Greten, F. R., Krahn, G., Bonizzi, G., et al. (2001). Activation by IKKalpha of a second, evolutionary conserved, NF-kappa B signaling pathway. Science 293, 1495-1499. doi: 10.1126/science.1062677

Seo, S. K., Seo, D. I., Park, W. S., Jung, W. K., Lee, D. S., Park, S. G., et al. (2014). Attenuation of IFN-gamma-induced B7-H1 expression by 15deoxy-delta(12,14)-prostaglandin J2 via downregulation of the Jak/STAT/IRF-1 signaling pathway. Life Sci. 112, 82-89. doi: 10.1016/j.lfs.2014.07.021

Sharma, A. M., and Staels, B. (2007). Review: Peroxisome proliferator-activated receptor gamma and adipose tissue-understanding obesity-related changes in regulation of lipid and glucose metabolism. J. Clin. Endocrinol. Metab. 92, 386-395. doi: 10.1210/jc.2006-1268

Shi, J., Johansson, J., Woodling, N. S., Wang, Q., Montine, T. J., and Andreasson, K. (2010). The prostaglandin E2 E-prostanoid 4 receptor exerts anti-inflammatory effects in brain innate immunity. J. Immunol. 184, 7207-7218. doi: 10.4049/ jimmunol.0903487

Shibata, T., Kondo, M., Osawa, T., Shibata, N., Kobayashi, M., and Uchida, K. (2002). 15-deoxy-delta 12,14-prostaglandin J2. A prostaglandin D2 metabolite generated during inflammatory processes. J. Biol. Chem. 277, 10459-10466.

Shibata, T., Yamada, T., Ishii, T., Kumazawa, S., Nakamura, H., Masutani, H., et al. (2003a). Thioredoxin as a molecular target of cyclopentenone prostaglandins. J. Biol. Chem. 278, 26046-26054. doi: 10.1074/jbc.m303690200

Shibata, T., Yamada, T., Kondo, M., Tanahashi, N., Tanaka, K., Nakamura, H., et al. (2003b). An endogenous electrophile that modulates the regulatory mechanism of protein turnover: inhibitory effects of 15-deoxy-Delta 12,14-prostaglandin J2 on proteasome. Biochemistry 42, 13960-13968. doi: 10.1021/bi035 $215 \mathrm{a}$

Signorini, C., De Felice, C., Leoncini, S., Giardini, A., D’Esposito, M., Filosa, S., et al. (2011). F(4)-neuroprostanes mediate neurological severity in Rett syndrome. Clin. Chim. Acta. 412, 1399-1406. doi: 10.1016/j.cca.2011.04.016

Stamatakis, K., and Perez-Sala, D. (2006). Prostanoids with cyclopentenone structure as tools for the characterization of electrophilic lipid-protein interactomes. Ann. N. Y. Acad. Sci. 1091, 548-570. doi: 10.1196/annals.1378. 096

Stocker, R., and Keaney, J. F. Jr. (2004). Role of oxidative modifications in atherosclerosis. Physiol. Rev. 84, 1381-1478. doi: 10.1152/physrev.00047.2003

Straus, D. S., and Glass, C. K. (2001). Cyclopentenone prostaglandins: new insights on biological activities and cellular targets. Med. Res. Rev. 21, 185-210. doi: 10.1002/med.1006

Straus, D. S., Pascual, G., Li, M., Welch, J. S., Ricote, M., Hsiang, C. H., et al. (2000). 15-deoxy-delta 12,14-prostaglandin J2 inhibits multiple steps in the NF-kappa B signaling pathway. Proc. Natl. Acad. Sci. U S A. 97, 4844-4849. doi: 10.1073/pnas.97.9.4844

Sun, S. C. (2017). The non-canonical NF-kappaB pathway in immunity and inflammation. Nat. Rev. Immunol. 17, 545-558. doi: 10.1038/nri.2017.52

Tae, I. H., Park, E. Y., Dey, P., Son, J. Y., Lee, S. Y., Jung, J. H., et al. (2018). Novel SIRT1 inhibitor 15-deoxy-Delta12,14-prostaglandin J2 and its derivatives exhibit anticancer activity through apoptotic or autophagic cell death pathways in SKOV3 cells. Int. J. Oncol. 53, 2518-2530.

Takashima, T., Fujiwara, Y., Higuchi, K., Arakawa, T., Yano, Y., Hasuma, T., et al. (2001). PPAR-gamma ligands inhibit growth of human esophageal adenocarcinoma cells through induction of apoptosis, cell cycle arrest and reduction of ornithine decarboxylase activity. Int. J. Oncol. 19, 465-471.

Tauber, D., and Parker, R. (2019). 15-Deoxy-Delta(12,14)-prostaglandin J2 promotes phosphorylation of eukaryotic initiation factor 2alpha and activates the integrated stress response. J. Biol. Chem. 294, 6344-6352. doi: 10.1074/jbc. ra118.007138

Vane, J. R., and Botting, R. M. (1990). The mode of action of anti-inflammatory drugs. Postgrad. Med. J. 66(Suppl. 4), S2-S17.

Varmus, H. E., Shank, P. R., Hughes, S. E., Kung, H. J., Heasley, S., Majors, J., et al. (1979). Synthesis, structure, and integration of the DNA of RNA tumor viruses. Cold Spr. Harb. Symp. Quant. Biol. 43(Pt 2), 851-864. doi: 10.1101/sqb.1979. 043.01.091

Vijay, R., Fehr, A. R., Janowski, A. M., Athmer, J., Wheeler, D. L., Grunewald, M., et al. (2017). Virus-induced inflammasome activation is suppressed by prostaglandin D2/DP1 signaling. Proc. Natl. Acad. Sci. U S A. 114, E5444E5453.

Wang, N., Liang, H., and Zen, K. (2014). Molecular mechanisms that influence the macrophage m1-m2 polarization balance. Front. Immunol. 5:614.

Wang, S. Z., Hallsworth, P. G., Dowling, K. D., Alpers, J. H., Bowden, J. J., and Forsyth, K. D. (2000). Adhesion molecule expression on epithelial cells infected with respiratory syncytial virus. Eur. Respir. J. 15, 358-366. doi: 10.1034/j.13993003.2000.15b23.x

Welch, J. S., Ricote, M., Akiyama, T. E., Gonzalez, F. J., and Glass, C. K. (2003). PPARgamma and PPARdelta negatively regulate specific subsets of lipopolysaccharide and IFN-gamma target genes in macrophages. Proc. Natl. Acad. Sci. U S A. 100, 6712-6717. doi: 10.1073/pnas. 1031789100

Welliver, R. C., Garofalo, R. P., and Ogra, P. L. (2002). Beta-chemokines, but neither $\mathrm{T}$ helper type 1 nor $\mathrm{T}$ helper type 2 cytokines, correlate with severity of illness during respiratory syncytial virus infection. Pediatr. Infect Dis. J. 21, 457-461. doi: 10.1097/00006454-200205000-00033

Wen, Z., Song, H., and Ming, G. L. (2017). How does Zika virus cause microcephaly? Genes Dev. 31, 849-861. doi: 10.1101/gad.298216.117

Wesselingh, S. L., Glass, J., McArthur, J. C., Griffin, J. W., and Griffin, D. E. (1994). Cytokine dysregulation in HIV-associated neurological disease. $A d v$. Neuroimmunol. 4, 199-206. doi: 10.1016/s0960-5428(06)80258-5

Whelan, J., and Fritsche, K. (2013). Linoleic acid. Adv. Nutr. 4, 311-312.

Wu, H. C., Wang, Q., Yang, H. I., Ahsan, H., Tsai, W. Y., Wang, L. Y., et al. (2008). Urinary 15-F2t-isoprostane, aflatoxin B1 exposure and hepatitis B virus infection and hepatocellular carcinoma in Taiwan. Carcinogenesis 29, 971-976. doi: 10.1093/carcin/bgn057

Xin, X., Yang, S., Kowalski, J., and Gerritsen, M. E. (1999). Peroxisome proliferatoractivated receptor gamma ligands are potent inhibitors of angiogenesis in vitro and in vivo. J. Biol. Chem. 274, 9116-9121. doi: 10.1074/jbc.274.13.9116

Yagami, T., Yamamoto, Y., and Koma, H. (2018). Physiological and Pathological Roles of 15-Deoxy-Delta(12,14)-Prostaglandin J2 in the Central Nervous System and Neurological Diseases. Mol. Neurobiol. 55, 2227-2248. doi: 10. 1007/s12035-017-0435-4

Yamakawa, K., Hosoi, M., Koyama, H., Tanaka, S., Fukumoto, S., Morii, H., et al. (2000). Peroxisome proliferator-activated receptor-gamma agonists increase vascular endothelial growth factor expression in human vascular smooth muscle cells. Biochem. Biophys. Res. Commun. 271, 571-574. doi: 10.1006/bbrc. 2000.2665

Yamamoto, N., Fukushima, M., Tsurumi, T., Maeno, K., and Nishiyama, Y. (1987). Mechanism of inhibition of herpes simplex virus replication by delta 7-prostaglandin A1 and delta 12-prostaglandin J2. Biochem. Biophys. Res. Commun. 146, 1425-1431. doi: 10.1016/0006-291x(87)90809-6

Yamamoto, Y., Koma, H., and Yagami, T. (2020). 15-Deoxy-Delta(12,14)prostaglandin J2 Inhibits Cell Migration on Renal Cell Carcinoma via DownRegulation of Focal Adhesion Kinase Signaling. Biol. Pharm. Bull. 43, 153-157. doi: 10.1248/bpb.b19-00748

Yen, C. C., Hsiao, C. D., Chen, W. M., Wen, Y. S., Lin, Y. C., Chang, T. W., et al. (2014). Cytotoxic effects of 15d-PGJ2 against osteosarcoma through ROSmediated AKT and cell cycle inhibition. Oncotarget 5, 716-725. doi: 10.18632/ oncotarget.1704 
Yoshida, M., and Seiki, M. (1987). Recent advances in the molecular biology of HTLV-1: trans-activation of viral and cellular genes. Annu Rev. Immunol. 5, 541-559. doi: 10.1146/annurev.iy.05.040187.002545

Yuan, J., Takahashi, A., Masumori, N., Uchida, K., Hisasue, S., Kitamura, H., et al. (2005). Ligands for peroxisome proliferator-activated receptor gamma have potent antitumor effect against human renal cell carcinoma. Urology 65, 594-599. doi: 10.1016/j.urology.2004.10.019

Zheng, J., Sariol, A., Meyerholz, D., Zhang, Q., Abrahante Llorens, J. E., Narumiya, S., et al. (2020). Prostaglandin D2 signaling in dendritic cells is critical for the development of EAE. J. Autoimmun. 114:102508. doi: 10.1016/j.jaut.2020. 102508

Zimta, A. A., Cenariu, D., Irimie, A., Magdo, L., Nabavi, S. M., Atanasov, A. G., et al. (2019). The Role of Nrf2 Activity in Cancer Development and Progression. Cancers 11:11.
Zingarelli, B., and Cook, J. A. (2005). Peroxisome proliferator-activated receptorgamma is a new therapeutic target in sepsis and inflammation. Shock 23, 393-399. doi: 10.1097/01.shk.0000160521.91363.88

Conflict of Interest: The authors declare that the research was conducted in the absence of any commercial or financial relationships that could be construed as a potential conflict of interest.

Copyright (c) 2021 Lee, Paing and Sharma-Walia. This is an open-access article distributed under the terms of the Creative Commons Attribution License (CC BY). The use, distribution or reproduction in other forums is permitted, provided the original author(s) and the copyright owner(s) are credited and that the original publication in this journal is cited, in accordance with accepted academic practice. No use, distribution or reproduction is permitted which does not comply with these terms. 